\title{
The Determinants of Debt Maturity Structure: Evidence from France, Germany and UK
}

\author{
Antonios Antoniou \\ University of Durham \\ Email: antonios.antoniou@durham.ac.uk \\ Yilmaz Guney \\ University of Surrey \\ Email:y.guney@surrey.ac.uk \\ Krishna Paudyal \\ University of Durham \\ Email: K.N.Paudyal@durham.ac.uk
}

Cite as: Antoniou, A., Guney, Y. and Paudyal, K., 2006. The determinants of debt maturity structure: evidence from France, Germany and the UK. European Financial Management, 12(2), pp.161-194.

We are grateful to John Doukas (the editor), George Philippatos, David Wright, Andrew Roper, Benjamin Esty and an anonymous referee for their valuable comments and suggestions on earlier versions of this paper. Any remaining errors are our own. Please address correspondence to Krishna Paudyal, Department of Economics and Finance, Durham Business School, Mill Hill Lane, Durham, DH1 3LB, UK, Email K.N.Paudyal@durham.ac.uk 


\title{
The Determinants of Debt Maturity Structure: Evidence from France, Germany and UK
}

\begin{abstract}
We examine the determinants of the debt maturity structure of French, German and British firms. These countries represent different financial and legal traditions that may have implications on corporate debt maturity structure. Our model incorporates the factors representing three major theories (tax considerations, liquidity and signalling, and contracting costs) of debt maturity. It also controls for capital market conditions. The results confirm the applicability of most theories of debt maturity structure for the UK firms. However, the evidence from France and Germany are mixed. Therefore, the findings suggest that the debt maturity structure of a firm is determined by firm-specific factors and the country's financial systems and institutional traditions in which it operates.
\end{abstract}

Keywords: Dynamic Debt Maturity Structure, Panel Data, System-GMM

JEL Classification: G20, G32 


\section{The Determinants of Debt Maturity Structure: Evidence from France, Germany and UK}

\section{Introduction}

In the presence of market imperfections, the need for an appropriate mix of debts stems from the golden rule of finance that sources and uses of funds need to be matched inter-temporally and cross-sectionally since a mismatch may lead to an inefficient liquidation of a positive-NPV firm/project. An important element of fund matching is the choice between short and long-term debts. The existing literature offers three main strands of debt maturity theories. The first is based on the tax minimisation objective of firms. Brick and Ravid (1985) suggest that when the term-structure of interest rates is upward sloping, long-term debt is optimal since interest tax shield from leverage is accelerated ${ }^{1}$. The second is based on information asymmetries that lead to liquidity risk and signalling. Fama (1990) suggests that the debt maturity structure reflects the incentive to provide information, monitoring and bonding relevant for contracts. Flannery (1986) predicts that high-quality firms prefer short-term debt to signal their quality. The third strand deals with contracting costs. Myers (1977) argues that short-term debt mitigates the underinvestment problem. Barnea et al. (1980) show that short-term debt may mitigate the asset substitution problem since the value of short-term debt is less sensitive to changes in firms' asset value. More importantly, however, asymmetric information arguments and contracting costs hypothesis jointly suggest that firms match the maturity of their assets and liabilities (Hart and Moore, 1994).

In spite of a number of theoretical explanations, empirical studies dedicated to the identification of the determinants of debt maturity are relatively new. Earlier studies examine this issue indirectly. For instance, Titman and Wessels (1988) report an inverse relation between firm size and short-term debt and Mitchell (1993) reports a negative relation between debt maturity and leverage and a positive relation between maturity and firm's quality. Recent studies on the determinants of debt maturity structure examine one hypothesis at a time. For instance, Kim et al. (1995) report a significant positive association of debt maturity with leverage and firm size. Barclay and Smith (1995) show that larger firms with lower market-to-book ratio borrow for longer terms. Guedes and Opler (1996) find that larger, better quality and high growth firms issue more short-term debts. Stohs and Mauer (1996), however, find mixed evidence of inverse relationship between debt maturity and market-to-book ratio. Scherr and Hulburt (2001) find little evidence that tax status, growth options, and information asymmetries affect small firms' debt

\footnotetext{
${ }^{1}$ Brick and Ravid (1991) show the optimality of long-term debt even if the yield curve is downward sloping or flat when the interest rates are uncertain. However, such patterns of yield curve are rare in markets.
} 
maturity choice. On the other hand, capital structure, liquidity risk and the matching of the maturities of assets and liabilities are found to be relevant in debt maturity decisions.

The lack of consistency in findings reported in the literature provides a strong motivation for further examination of the determinants of debt maturity. The main contribution of this paper is the estimation of an integrated model that incorporates several factors representing all major theories of the determinants of debt maturity structure. In particular, this approach offers an opportunity to test various theories of the determinants of debt maturity (e.g. tax savings, immunisation, information asymmetry, contracting costs etc.) and market conditions in a single model, and contributes in resolving some of the discrepancies reported in the literature.

The paper makes the following further contributions. First, it offers 'out of sample' tests of existing theories, primarily originating from the US experience, by providing a comparative picture of three major European Markets ${ }^{2}$. Our sample countries (France, Germany and the UK) represent three distinct legal and financial traditions ${ }^{3}$. Second, we include a new set of variables (term-structure of interest rates, stock returns, and equity premium) that captures the effects of equity market conditions on corporate debt maturity structure. This creates a link between equity and debt markets and sheds light on whether managers combine information from both markets while making debt maturity decisions. Third, the estimation method that we use controls for the endogeneity that may arise from random shocks affecting both debt maturity and its determinants simultaneously. Finally, the speed of the adjustment process in attaining the optimal debt maturity structure is examined using a dynamic model.

The findings reveal that there are considerable differences in debt maturity patterns in France, Germany and the UK. Most hypotheses that are identified in the literature hold for British firms but not for French and German. The rest of the paper is organised as follows. Section II describes the variables and related hypotheses. Section III discusses the data and sample. Methodology, models and their robustness tests are discussed in section IV. Section V presents the results. Finally, section VI concludes the paper.

\section{Theories, Variables and Hypotheses Development}

This section develops testable propositions and provides justifications for each variable included in the analysis in the context of the major theories of corporate debt maturity structure.

\footnotetext{
${ }^{2}$ Recent studies (for instance, Fan et al. (2003)) suggest that cross-country heterogeneity in institutional factors might be responsible for the observed diversity in corporate financial decisions around the world.

${ }^{3}$ La Porta et al. (1998) quantifies some measures of institutional differences across the countries. For a detailed discussion on the possible implications of financial and institutional traditions on financing decisions of companies in France, Germany and the UK see Antoniou et al. (2002).
} 


\subsection{The Dependent Variable: Measuring Maturity}

There is no universal definition of short- or long-term debt. Following accounting conventions some studies (for example, Scherr and Hulburt, 2001) consider a debt as long-term if it is payable after a year, while others define it as long-term if it is payable after three (Barclay and Smith, 1995) or five years (Schiantarelli and Sembenelli, 1997). Similarly, Stohs and Mauer (1996) use weighted average maturity of liabilities; Scherr and Hulburt (2001) use two maturity specifications, (a) long-term debt payable after one year to total debt ratio, and (b) weightedaverage debt maturity. They, in general, report only a minor sensitivity of the results to the choice of definition. Following accounting conventions, we define long-term debt as the debt maturing in more than one year and the maturity ratio is defined as long-term debt divided by total debt. This choice is also driven by data availability ${ }^{4}$.

\subsection{Explanatory Variables: Reasoning and Measurement}

Four main hypotheses of the determinants of debt maturity structure and the associated variables are discussed below. The hypotheses are based on: (a) tax minimisation, (b) liquidity risk and signalling, (c) contracting costs, and (d) equity market conditions. These hypotheses are not mutually exclusive and a given variable may represent more than one hypothesis with the same or opposing effect. Further, due to a number of known limitations and comparability problems associated with accounting information, the proxies used can be far from perfect. Therefore, where appropriate, more than one variable is used to represent different dimensions of a theory. To examine the robustness of the results, where possible, the models are estimated using alternative definition of the variables.

\subsubsection{Tax minimisation}

The corporate tax rate, the term-structure of interest rates and the uncertainty in the rate of interest interact to offer tax incentives in debt maturity structure. Brick and Ravid (1985) argue that when the term structure of interest rates is upward sloping, long-term debt is optimal since tax gains are accelerated. However, assuming that taxation is the only market imperfection, Lewis (1990) argues that taxation has no effect on debt maturity decisions if optimal leverage and debt maturity are simultaneously determined. In a multi-period model with uncertain interest rate, Kim et al. (1995) demonstrate that a long-term debt maturity strategy maximises investor's tax-timing option value, where the choice is between repurchasing and reissuing the debt. This model predicts that a firm lengthens debt maturity as the interest rate volatility and the slope of

\footnotetext{
${ }^{4}$ Some firms consider the recurrent component of short-term debt as long-term debt in their balance sheet. Moreover, firms using creative accounting have several possibilities to reduce their reported debt and alter their category. Therefore, there are apparent accounting difficulties in measuring long and shortterm debts. We are grateful to the referee for drawing our attention to these limitations.
} 
the term structure increases ${ }^{5}$. Kane et al. (1985) argue that optimal maturity is negatively associated with tax advantage of debt and the volatility of firm value and positively correlated with flotation costs. Hence, tax rates and debt maturity should be inversely related to ensure that the tax benefits of debt are not less than the amortised flotation costs.

Scholes and Wolfson (1992) propose a tax clientele argument to predict the relationship between debt maturity and taxation. They argue that not all firms can afford to issue 'expensive' long-term debt, although the transaction costs of rolling-over short-term debt are higher. Thus, corporations with high marginal tax rates represent a natural clientele of 'cheap' long-term debt as they can use the ongoing tax advantages of long-term debt.

Thus, the tax hypothesis is represented by three factors: (a) the effective tax rate, (b) the term structure of interest rate, and (c) the volatility in interest rate. We measure the effective tax rate by the ratio of tax paid to taxable income. The term structure of interest rates is the difference between the month-end yields on long-term (10 years or more) government bonds and threemonths treasury-bills, matched to the month of the firm's fiscal year-end (a six-month lag is used to allow for the time gap between decision making and actual issue of debt). Interest rates volatility is the standard deviation of the monthly government bond yield over the previous year, matched with the month of firm's fiscal year-end.

\subsubsection{Liquidity Risk and Signalling}

This hypothesis suggests that the capital structure, liquidity and volatility of earnings and firm value interact to influence the debt maturity decisions of managers and the managers are motivated in reducing the bankruptcy risk.

Leverage: Leland and Toft (1996) show firms opting for higher leverage also choose longer maturity. Morris (1992) suggests that firms with higher debt tend to issue longer-term debt in order to delay their exposure to bankruptcy risk. On the other hand, Dennis et al. (2000) argue that leverage and maturity should be inversely related as the agency costs of underinvestment can be mitigated by reducing leverage as well as by shortening debt maturity. Therefore, the nature of relation between leverage and debt maturity remains an empirical question. To examine the robustness of estimates we measure leverage in three ways. They are: (a) the ratio of book value of total debt to book value of total assets, (b) the ratio of book value of total debt to market value of equity plus book value of total debt, and (c) the ratio of total debt less cash and equivalent to total assets.

\footnotetext{
${ }^{5}$ On the contrary, Stohs and Mauer (1996) find a negative association between the slope of the yield
} 
Liquidity: Myers and Rajan (1998) argue that a high liquidity ratio may reduce the fund raising capacity of firms, as excessive liquidity reduces the managers' ability to commit credibly to an investment action. Non-depreciating assets (e.g. land) are linked to increased debt maturity. However, non-depreciating but liquid assets (e.g. inventories) do not support long-term debt. In buying long-term bonds, lenders are exposed to the risk that the firm's conditions may deteriorate over time or the management may shift to riskier projects before the bonds mature. Thus, lenders may impose restrictions on long-term borrowing to control for such risks and hence the firms with higher liquidity will be able to raise long-term debt. To examine the robustness of estimation we measure the liquidity in two ways: (a) the ratio of current assets to total assets, and (b) the ratio of current assets to current liabilities (working capital ratio).

Firm level volatility: Kane et al. (1985) and Sarkar (1999) showed that the debt maturity is inversely related to the volatility of firm's value. Low variability in firm value inspires the managers to avoid rebalancing their capital structure frequently. Aiming at avoiding the potential risk of bankruptcy, such firms issue long-term debt rather than short-term debt. The firm level volatility is measured by volatility in earnings ${ }^{6}$. It is estimated as the absolute value of change in earnings (EBITD) minus average earnings change.

Firm's quality: The signalling hypothesis implies that firms with high asymmetric information problems and high-quality projects choose to issue shorter-term debt (Mitchell, 1991). Under asymmetric information, Flannery (1986) argues that long-term debt, which is more sensitive to firm value, can potentially be more mis-priced than short-term debt. Hence, high (low) quality firms are likely to issue less (more) undervalued (overvalued) short (long) -term debt. He also shows that low-quality firms cannot afford to rollover short-term debt due to positive transaction costs, and thus opt for long-term debt. Confirming the theoretical prediction of Flannery (1986), Datta and Iskandar-Datta (2000) empirically find a negative relation between long-run abnormal returns and the maturity of debt-IPOs. For the same reason, we expect a negative relationship between firm quality and debt maturity. To examine the robustness of our results we measure firm quality in two ways: (a) the ratio of net income plus depreciation to net debt, and (b) the ratio of shareholders funds to net debt.

In summary, liquidity risk and signalling hypothesis are represented by four factors - leverage, liquidity, firm level volatility, and firm's quality - in our model.

curve and debt maturity due to the attempts of firms to avoid term premium in long-term interest rates. 6 In the absence of reliable cash-flow data, empirical studies measure volatility of firm value by volatility in earnings (see, for instance, Stohs and Mauer, 1996). 


\subsubsection{Contracting Cost}

This hypothesis suggests that short-term debts offer better monitoring opportunities for lenders as the managers need to approach lenders more frequently to renew short-term debts. Therefore, firms requiring close/frequent monitoring are forced to opt for short-term debts.

Growth opportunities: Myers (1977) suggests that agency related underinvestment problems are mitigated if growth firms use short-term debts that expire before exercising the growth options, thereby borrowers and lenders can renegotiate. Similarly, the agency cost of monitoring may be reduced if firms are evaluated periodically by issuing short-term debts. Titman (1992) argues that if growth firms have both greater likelihood of bankruptcy and optimistic future-outlook, they can benefit from borrowing for short-term. Thus, growth opportunity should be inversely related to debt maturity. However, the liquidity risk argument (Diamond, 1991) predicts that firms with long-term investment opportunities - requiring ongoing managerial discretion - prefer to hedge against liquidity risk by issuing long-term debts. Hart and Moore (1995) emphasise the role of long-term debt in controlling management's ability to raise funds for future projects. Long-term debts may prevent self-interested managers from financing unprofitable investment. This implies a direct relationship between long-term debt and growth opportunity. Therefore, the nature of the relationship between growth opportunity and debt maturity is an empirical issue. We measure growth opportunities by market-to-book ratio ${ }^{7}$.

Firm size: Arguably, larger firms have lower asymmetric information, higher tangible assets relative to future investment opportunities, and thus easier access to long-term debt markets. Agency problems between shareholders and lenders, such as risk shifting and claim dilution, may be particularly severe for small firms. Therefore, bondholders attempt to control the risk of lending to small firms by restricting the length of debt maturity. Thus, a positive relationship between firm size and debt maturity is expected. Firm size is measured in two ways: (a) the natural logarithm of total sales, and (b) the natural logarithm of total assets.

Asset maturity structure: The immunisation hypothesis suggests that firms match their debt maturity to their asset maturity. This principle has been widely accepted, as it controls for the risk and costs of financial distress. Hart and Moore (1994) confirm the matching principle by showing that slower asset depreciation means longer debt maturity. In a survey of 392 US firms, Graham and Harvey (2001) find that matching maturity between liabilities and assets is

\footnotetext{
${ }^{7}$ Data on alternative proxies of growth (e.g. R\&D plus advertising expenses to total assets ratio) are not available.
} 
important in choosing whether to issue short or long-term debt. Therefore, we expect a positive relationship between debt maturity and asset maturity. We measure asset maturity by the ratio of net property, plant and equipment to depreciation.

Thus, the contracting (agency) cost hypothesis is represented by three variables, namely growth opportunities, firm size and asset maturity structure.

\subsubsection{Equity Market Conditions}

Most prior studies on debt maturity structure do not provide sufficient evidence relating to the influence of equity market conditions. However, since managers are expected to maximize the value of the firm through their decisions, they are unlikely to ignore the equity market conditions when deciding debt maturity.

Share price performance: The signalling hypothesis argues that undervalued firms issue shortterm debt to signal their undervaluation (Myers, 1984). Furthermore, Guedes and Opler (1996) state that past stock returns may be used as predictors of debt maturity, as it is generally expected that the issuing of informationally disadvantaged securities, such as long-term debt, would follow share price run-ups. We, thus, expect a positive correlation between debt maturity and past share price performance.

Equity risk premium: The equity premium measures the cost of equity in relation to the return on a risk-free investment. Baker and Wurgler (2000) find that firms tend to issue equity instead of debt when the future cost of equity is relatively low. It is also argued that expected bond returns are relatively low when business conditions are good. This is due to higher equity returns (and premium) reflecting profitable investment opportunities. This inspires the value enhancing managers to raise debt (long-term), instead of equity, when the equity premium is high.

In summary, the above two factors represent equity market conditions, which may impact on debt maturity decision. The share price performance is measured by the first difference of log of annual prices and the equity premium is measured by the difference between the return on equity and the return on treasury-bills, matched to the month of the firm's fiscal year-end. To allow for a time gap between the decision making process and the issuance of debt, both variables are used with six month lags.

\subsection{Debt Maturity Dynamics: Lagged Maturity}

The inclusion of the lagged dependent variable, debt maturity, on the right-hand side of the equation allows for the testing of the existence of a target optimal debt maturity structure and, if 
it exists, of the degree of divergence (convergence) from (to) the target level. Jalilvand and Harris (1984) find that firms partially adjust to their long-run financial targets. Tax, bankruptcy, and monitoring cost-related arguments predict a positive impact of lagged maturity, but the signalling hypothesis implies that this factor has no effect on debt maturity (Mitchell, 1993). A significant, positive and less than unit coefficient of lagged debt maturity variable would suggest that the firms have a target optimal debt maturity structure. A greater than one coefficient would imply that firms do not have any target ratio.

Although in the above paragraphs several variables are grouped according to their principal predictions, some of the variables reveal information on the validity of more than one hypothesis. Table 1 summarises the empirical predictions of each of the determinants of debt maturity structure discussed in this section.

Table 1 about here

\section{The Sample}

The sample includes all non-financial firms traded (including delisted) in the stock exchanges of three major European countries (France, Germany and the UK) during the sample period. The sample period is guided by the availability of data. It starts from 1969, 1983 and 1987 for the UK, France and Germany respectively, and ends in 2000. To allow for the dynamic modelling, we exclude the firms with less than three consecutive observations (see Appendix A for further details). Data are obtained from Datastream.

Table 2 shows that the average long-term debt ratio is highest in France (59\%) and lowest in the UK (46\%), while its standard deviation is highest in the UK and lowest in France. The high dispersion reflects relatively wider cross-sectional as well as time series variation in the debt maturity structure of British firms. On average, the effective rate of tax is highest in Germany $(39 \%)$ followed by the UK (36\%). The asset maturity ratio is highest in the UK (13.6) and lowest in France (5.9). Such cross-country differences in other variables (see table 2 for other variables) imply substantial variations in the tradition and practices of corporate financial systems in these sample countries.

Table 2 about here

It is also possible that the financial markets have gone through major structural change during the sample period and the average relation obtained by pooling the data for such a long period may not reflect the true picture. To allow for this possibility we split the sample into two sub- 
sample periods. The market for short-term securities in France was opened in 1985 and expanded substantially in 1992 with the introduction of medium-term notes. This change offered opportunities to issue a range of fixed income securities that mature in a very short period to long period (Banque de France publications, 2002). This brought a major change in the structure of the corporate debt market in France. Therefore, we divide the French sample into two sub periods viz., 1983-1992 and 1993-2000. This change has resulted in a decline in the average proportion of long-term loan to total debt from $63 \%$ during $1983-1992$ to $57 \%$ during 1993-2000. In Germany until 1992 public issue of commercial papers and longer-term bonds were discouraged through the requirements of the issue authorisation procedure and the securities transfer tax. Since 1991, innovations in financial and legal traditions have affected the German financial markets considerably. Thus, we divide the German sample into two subsamples covering 1987-1992 and 1993-2000. Following this change, the proportion of long-term debt on total corporate debt of Germany has declined from $57 \%$ to $50 \%$ reflecting the ease at which firms can raise short-term debt by issuing commercial papers. The major change in British capital markets occurred in 1986. The Financial Services Act 1986 was introduced and the operation mechanisms of stock market were altered (known as Big Bang) in October 1986. Increasing transparency and reducing trading costs were some of the major motives of this change. Therefore, we split the UK sample into two sub-samples covering 1969-1986 and 19872000. Unlike in France and Germany the proportion of long-term debt on total debt has increased recently in the UK. This could be due to the ease and lower cost of issuing long-term securities following the change of 1986 and declining interest cost. Overall, these artefacts confirm that the changes in regulations do affect the debt maturity structure of corporate entities.

Correlation analysis (table 3) shows significant positive relation between maturity and leverage in all countries. The firm's quality has no substantive correlation with the debt maturity in any of the countries in the sample. The observed positive association of debt maturity with firm size in France and in the UK, and with asset maturity in all countries is supported by the theory. The effective tax rate is positively correlated only in Germany. However, market-to-book ratio is significantly inversely correlated with debt maturity in France and Germany. Stohs and Mauer (1996) suggest that if the leverage is strongly positively correlated to debt maturity and is strongly negatively correlated to market-to-book ratio, we should control for the effect of leverage in the model to prevent the downward bias in estimated coefficient of market-to-book ratio. The estimates in this paper show that this is the case for all countries.

Table 3 about here 


\section{The Methodology}

This section provides a discussion on the appropriateness of alternative methods of estimation, such as OLS, instrumental variables, traditional difference-GMM, as well as recently developed system-GMM methods. Each method is applied in testing the determinants of debt maturity and the validity of all methods of estimation examined. In the extant literature, the endogeneity problem is either largely ignored, or only corrected using fixed effects or control variables. This study controls for this crucial problem and avoids significant bias in estimates by employing a more advanced method of GMM.

\subsection{The model}

Our model of corporate debt maturity structure represents three major theories and market conditions. We examine these theories in a panel data framework. The main motivation for using panel data is to control for unobservable firm heterogeneity. Dennis et al (2000) criticise previous studies on the use of the exogeneity assumption that causes bias in estimates. This study controls for this problem. Furthermore, most previous studies on the determinants of corporate debt maturity use period average cross sectional data rather than panel data. The advantages of panel data include increased degrees of freedom owing to the availability of large number of observations, and reduced collinearity among explanatory variables leading to efficient estimates. A partial adjustment model is adopted to investigate the presence of target debt maturity structure. To achieve a complete dynamic specification, allowing for a possible ARprocess, and to examine the adjustment cost effect, the lagged dependent variable and lagged explanatory variables are incorporated in the model as in equation (1):

$$
Y_{(i t)}=\beta_{0}+\beta_{1} Y_{i(t-1)}+\sum_{k=1} \gamma_{k} X^{a}{ }_{k i t}+\sum_{k=1} \delta_{k} X_{k i(t-1)}^{b}+v_{i}+v_{t}+\varepsilon_{i t}
$$

The dependent variable, $Y_{i t}$, is a measure of the debt maturity of firm $i$ in year $t . X^{a}$ and $X^{b}$ are vectors of current and lagged explanatory variables respectively. $v_{i}$ represents time-invariant unobservable firm-specific effects, such as reputation and capital intensity; and $v_{t}$ represents time-specific effects (e.g. interest rates and demand shocks) which are common to all firms and can change overtime. $\beta_{0}, \beta_{1}, \gamma_{s}$ and $\delta_{s}$ are unknown parameters to estimate. The time-varying disturbance term $\varepsilon_{\text {it }}$ is serially uncorrelated with mean zero and variance $\sigma^{2}$. The explanatory variables ( $k=1$ to12) are: (1) Effective tax rate, (2) Term structure of interest rates, (3) Interest rate volatility, (4) Leverage, (5) Liquidity, (6) Firm level volatility, (7) Firm quality, (8) Growth opportunity, (9) Firm size, (10) Asset maturity, (11) Share price performance, and (12) Market equity premium. See section II for their definition and measurement. 


\subsection{The methods of estimation}

Estimating equation (1) using an OLS technique would not produce unbiased coefficients because $v_{i}$ is unobservable and correlated with other regressors in the model (Hsiao (1985)). Since some lagged dependent variables may be correlated with firm-specific effects, the estimates may be inconsistent. Although it is possible to eliminate $v_{i}$ by first-differencing, the OLS estimators are still inefficient, since $\Delta \varepsilon_{i t}$ and $\Delta \mathrm{Y}_{\mathrm{i}(\mathrm{t}-1)}$ are correlated as a consequence of the correlation between $\varepsilon_{i(t-1)}$ and $Y_{i(t-1)}$. In addition, OLS assumes that all the explanatory variables are strictly exogenous which may not the case in debt maturity decisions.

Anderson and Hsiao (1982) propose an instrumental variables (IV) technique to overcome the above problems. They suggested that $\Delta \mathrm{Y}_{\mathrm{i}(\mathrm{t}-2)}$, or $\mathrm{Y}_{\mathrm{i}(\mathrm{t}-2)}$, can be used as instrument for $\Delta \mathrm{Y}_{\mathrm{i}(\mathrm{t}-1)}$. This instrument selection is relevant and valid because $\Delta \mathrm{Y}_{\mathrm{i}(\mathrm{t}-2)}$, or $\mathrm{Y}_{\mathrm{i}(\mathrm{t}-2)}$, is correlated with $\Delta \mathrm{Y}_{\mathrm{i}(\mathrm{t}-1)}$, but not with $\Delta \varepsilon_{i t}$. If $\varepsilon_{i t}$ is not serially correlated then the IV estimates will be consistent. However, since the IV technique neither uses all the related moment conditions, nor accounts for the differenced structure of the error term, the estimates are unlikely to be efficient.

Arellano and Bond (1991) suggest that GMM controls for these problems. GMM employs additional instruments obtained by utilising the orthogonal conditions that exist between the error term $\left(\varepsilon_{i t}\right)$ and the lagged dependent variable. Therefore, GMM optimally exploits all the linear moment restrictions specified by the model, the main advantage of the GMM technique. It is argued that $E\left(\varepsilon_{\mathrm{it}}, \varepsilon_{\mathrm{it}-1}\right)$ in equation (1) is not necessarily zero, but $E\left(\varepsilon_{\mathrm{it}}, \varepsilon_{\mathrm{it}-2}\right)$ should be zero as the consistency of GMM estimators is based on the absence of second-order correlation in differences and of first-order correlation in levels. If we assume that the error terms are not correlated, it is expected that $\Delta \varepsilon_{i t}$ is orthogonal to the history of the variables $\mathrm{X}$ and $\mathrm{Y}$ so that $\left(\mathrm{X}_{\mathrm{it}-}\right.$ 2, $\left.\mathrm{X}_{\mathrm{it}-3, \ldots} \mathrm{Y}_{\mathrm{it}-2,}, \mathrm{Y}_{\mathrm{it}-3, \ldots)}\right)$ can be used as valid instruments for $\Delta \varepsilon_{\mathrm{it}-\text { If }} \varepsilon_{\mathrm{it}}$ follows an MA(1) process, then

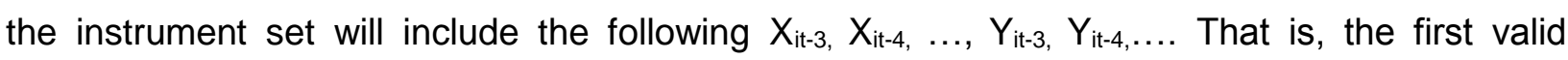
instruments starts from the third lag, not from the second, because the differenced-disturbances follow an MA(2) process. Consequently, it is essential that there is no higher-order serial correlation to have a valid set of instruments independent from the residuals. One can investigate this by the use of Sargan test of over identifying restrictions.

We apply the two-step GMM estimators that use one-step residuals to construct the asymptotically optimal weighting matrix. This is more efficient than the one-step estimators when the disturbances are expected to show heteroscedasticity in the large sample data with a relatively long time span. This can control the correlation of errors overtime, heteroscedasticity 
across firms, simultaneity and measurement errors due to the utilisation of the orthogonality conditions on the variance-covariance matrix.

The discussion above reveals that the GMM specification of the first differences (GMM-DIF) is superior to many other methods. However, recent research shows that the GMM-DIF estimator has a problem related to weak instruments. It is known that first-differencing causes information loss across cross-section units (firms, in our case) and exacerbates measurement error biases. Arellano and Bover (1995) argue that the absence of information with respect to the parameters in the level variables causes substantial loss of efficiency in models estimated in first-differences using instruments in levels. They propose the use of instruments in first differences for equations in levels and instruments in levels for equations in first differences. Blundell and Bond (1998) show that this system-GMM (GMM-SYS) estimator of Arellano and Bover (1995) has dramatic efficiency gains in cases where GMM-DIF estimator performs poorly especially for short sample period and persistent data ${ }^{8}$. This poor performance is particularly apparent when the coefficient estimate of the lagged dependent variable approaches unity and the ratio of [variance $\left(v_{i}\right) /$ variance $\left.\left(\varepsilon_{i t}\right)\right]$ increases (see equation (1)). In such cases, the coefficient of lagged dependent variable is downward-biased. Moreover, Blundell and Bond (1998) report that once lagged first-differenced and lagged-levels instruments are incorporated into the instrument set, the finite sample bias can be reduced considerably by exploiting the additional moment conditions coming from level equations. They show that the instruments used by the GMM-DIF estimator contain little information about the endogenous variables in first differences, and lagged first differences are informative instruments for the endogenous variables in levels. In this way, apart from controlling for individual heterogeneity, one could partially capture variations between firms' characteristics. Thus, GMM-SYS seems to be the most appropriate method to estimate equation (1). However, the validity of the arguments for and against alternative methods of estimation is tested on the data set before discussing the economics of determinants of debt maturity structure in sample countries.

\subsection{Target maturity structure and speed of adjustment}

Static panel data models implicitly assume that firms are able to adjust their financing structure without any delay. However, we allow for any possible delay in adjusting the target maturity structure that may occur due to the presence of adjustment costs. This is investigated through adopting a partial adjustment process. Assume that the desired target maturity structure $\left(\right.$ Maturity $_{i t}^{*}$ ) is a function of $k$ explanatory variables as in equation (2):

\footnotetext{
8 Under the extended GMM-SYS technique, the model is estimated in both levels and first differences; that is, in stacked regressions level equations are simultaneously estimated using differenced lagged regressors as instruments.
} 


$$
\operatorname{Maturity}_{i t}^{*}=\sum_{k=1} \psi_{k} x_{k i t}+\omega_{i t}
$$

$\mathrm{x}$ is a vector of $\mathrm{k}$ explanatory variables; $\omega_{\mathrm{it}}$ is a serially correlated disturbance term with mean zero and possibly heteroscedastic; and $\psi_{k}$ 's are unknown parameters to estimate. The model assumes that firms adjust their current maturity structure (Maturity $\left.{ }_{i, t}\right)$ according to the degree of adjustment coefficient " $\rho$ ", to obtain the target maturity structure:

$$
\text { Maturity } \left._{i t}-\text { Maturity }_{i t-1}=\rho \text { Maturity }_{i t}^{*}-\text { Maturity }_{i t-1}\right)
$$

If $\rho=1$, then the actual change will be equal to the desired change. If $\rho=0$, however, no adjustments are made, implying that either the lagged level is the target level, or the cost of adjustment is higher than the cost of remaining off target. By combining equations (2) and (3) we obtain equation (4):

$$
\text { Maturity }_{i t}=(1-\rho) \text { Maturity }_{i t-1}+\sum_{k=1} \rho \psi_{k} x_{k i t}+\rho \omega_{t}
$$

Equation (4) assumes that $\rho$ lies between zero and unity. If the cost of being in disequilibrium is higher (lower) than the cost of adjustment then $\rho$ tends to unity (zero).

\subsection{Long-term relation}

The long-term relationship between corporate debt maturity and its determinants may differ from the short-term effects. Any difference in the sign of the coefficient of the contemporaneous and lagged values of the explanatory variables reveals this possibility (Blundell and Bond, 1998). We examine the long-run relationship by estimating equation (5).

$$
\begin{aligned}
& \text { Maturity }_{i t}^{*}=\left(\frac{\gamma_{1}+\delta_{1}}{1-\beta_{1}}\right) \text { Tax Rate }_{i t}^{*}+\left(\frac{\gamma_{2}+\delta_{2}}{1-\beta_{1}}\right) \text { Earnings Volatility }{ }_{i t}^{*}+\left(\frac{\gamma_{3}}{1-\beta_{1}}\right) \text { Term Structure }_{i t}^{*}+ \\
& \left(\frac{\gamma_{4}}{1-\beta_{1}}\right) \text { Interest Rate Volatility }{ }_{i t}^{*}+\left(\frac{\gamma_{5}+\delta_{5}}{1-\beta_{1}}\right) \text { Liquidity }_{i t}^{*}+\left(\frac{\gamma_{6}+\delta_{6}}{1-\beta_{1}}\right) \text { Leverage }_{i t}^{*}+ \\
& \left(\frac{\gamma_{7}+\delta_{7}}{1-\beta_{1}}\right) \text { Firm Quality }{ }_{i t}^{*}+\left(\frac{\gamma_{8}+\delta_{8}}{1-\beta_{1}}\right) \text { Market to Book }{ }_{i t}^{*}+\left(\frac{\gamma_{9}+\delta_{9}}{1-\beta_{1}}\right) \text { Firm Size }_{i t}^{*}+
\end{aligned}
$$

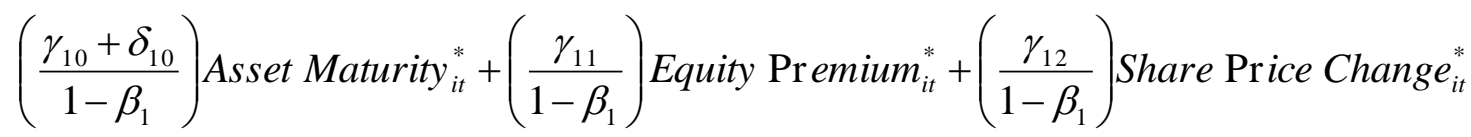

The parameters used in equation (5) ( $\beta, \gamma$ and $\delta$ ) are obtained from a dynamic estimation of equation (1). Since it is not easy to establish exogeneity in financial and accounting data, the direction of causation between variables could be problematic because of endogeneity. If, for instance, there has been a change in the market value of a firm in this year compared to last year, the source of this change should be obtained from last year's financial decisions. 
Therefore, using the contemporaneous data for both the maturity and the determinants may lead to spurious results. Our model does not suffer from this problem.

\section{The Results}

In order to examine whether the theoretical arguments about the various methods of estimation discussed above hold for our data set, equation (1) was estimated using OLS, Anderson-Hsiao type method, and GMM in levels and first differences. The results and diagnostics from these methods were then compared to those from the GMM-SYS method. The estimates confirmed the discussion in the method section and suggested that GMM-SYS is the most appropriate estimation technique.

The weak instruments problem discussed earlier in relation to GMM-DIF is apparent from a comparison of GMM-DIF results with fixed-effects estimates (WITHIN) in table 4. The results in this table are generally similar and the estimated coefficient of lagged maturity of GMM-DIF is not substantially higher than that of WITHIN. Hence, it confirms the downward bias in the lagged-maturity coefficient, showing the existence of a weak instruments problem. The arguments presented in the previous section, together with the findings in table 4, suggest that the most appropriate method to test dynamic debt maturity structure is the two-step GMM-SYS ${ }^{9}$. Our results are robust for many reasons. First, the potential endogeneity problem is eliminated by the GMM methodology. Second, the GMM process does not need the conditions of 'no autocorrelation', 'no heteroscedasticity', and 'normality' to be fulfilled especially for large samples. Third, our panel data set does not suffer from small sample bias, and asymptotic standard errors are robust to heteroscedasticity.

\section{Table 4 about here}

In order to examine whether the determinants of debt maturity are country specific, the data for all sample countries were pooled together and equation (1) estimated with dummies for the UK and Germany. A significant coefficient of the country dummy in the model would imply the presence of country specific factors in determining the debt maturity structure. Table 5 documents the GMM-SYS estimation results for this estimation. The dummy variable for the UK is significant at $1 \%$ implying that country-specific factors are important in corporate debt maturity decisions. This necessitates the estimation of the model for each individual country.

Table 5 about here

\footnotetext{
${ }^{9}$ Estimates of equation (1) in static form support the use of a dynamic GMM model.
} 


\subsection{Target Debt Maturity and Speed of Adjustment}

The positive, statistically significant and less than unit coefficients for the lagged maturity variable (table 6 ) suggest the presence of costly and non-instantaneous adjustments towards target maturity structure in all three countries ${ }^{10}$. This is consistent with the findings of Newberry and Novack (1999). The coefficient of lagged maturity (1- $\rho)$ suggests that the French firms have the highest adjustment speed. On the contrary, the adjustment process is relatively costly and slow in the UK. This implies that the cost of being off-target is not significantly higher than the cost of adjustment for British firms. The adjustment speed of German firms lies between the French and British cases. This trend holds for both sub-samples as well ${ }^{11}$. An analysis of subsample reveals that the speed of adjustment has increased in the recent years in France and the UK but declined in Germany. Overall, the results support the dynamic debt maturity structure decision as the firms in our sample countries seem to trade-off between adjustment costs and the costs of being off-target.

\section{Table 6 about here}

\subsection{Tax Minimisation}

Effective tax rate: The relation between the effective tax rate and debt maturity is country dependent (table 7). In line with the findings of Dennis et al. (2000), the tax rate's coefficient is insignificant for France and the UK. The significantly positive coefficient for Germany is consistent with the findings of Newberry and Novack (1999) supporting the tax clientele argument that firms with high marginal tax rates and with better ability to use interest tax shields issue long-term debt. This may be caused by the relatively higher rate of tax in Germany ${ }^{12}$. The insignificant coefficient of the UK firms could be attributed to the tax rule that allows firms to prepare separate accounts for tax computation and for public consumption. Moreover, the provisions of allowing firms to prepare group accounts and carry forward losses make it difficult to detect the actual influence of the effective tax rate on debt maturity. In the case of France, it is known that potential tax benefits are prone to diminish due to declining tax rates. Moreover, the effective tax rate in France is lower than in the UK and Germany (table 2). This reduces the importance of tax considerations in the debt maturity decision. Overall, in recent years the effective rate of tax has not played any significant role in determining the debt maturity structure of the firms in sample countries.

10 The 'specific' estimates in table 6 are obtained following the general-to-specific approach, i.e. by excluding the insignificant lagged explanatory variables from the estimation of a general dynamic model.

11 The estimates of sub-samples are not reported to conserve space.

12 The positive and significant coefficient is limited to the period prior to 1992. 
Interest rates and volatility: Estimates (table 7) show positive and significant effects of term structure of interest rates in Germany and the UK. This lends support to the tax hypothesis that long-term debt accelerates tax gains when the term-structure is upward sloping. However, its effect on debt maturity structure of French firms is negative ${ }^{13}$. The importance of term structure is sample period dependent as well. In the UK, its role is not significant in recent years. This could be due to low rate of interest in the recent years that is gradually declining since late 1980s. Table 7 further shows that effect of interest rate volatility on debt maturity structure is also country dependent. Its role is insignificant in France and Germany. However, its effect is negative and significant in the UK implying that British firms avoid entering into long-term commitments while the degree of uncertainty is high ${ }^{14}$.

Overall, the results suggest that the relationship between debt maturity and tax considerations (effective tax rate, the term structure of interests and the interest rate volatility) is rather weak and depends on sample period and country analysed.

\section{Table 7 about here}

\subsection{Liquidity Risk and Signalling}

Leverage: The estimates (table 7) reveal a significant and positive association between book leverage ratio and debt maturity in all countries ${ }^{15}$. This supports the view that firms with higher debt-ratios attempt to control for bankruptcy risk and the costs of financial distress by lengthening their debt maturity. However, this finding rejects the monitoring hypothesis that shorter maturity decreases agency costs by accelerating the frequency of creditors' audit. A sub-sample analysis shows that the effect of leverage on debt maturity is period dependent, being more prominent in the recent years.

Liquidity: The association between debt maturity and liquidity is negative and significant in all sample countries (table 7). A similar relation is observed in both sub-sample periods except in the case of France where it is significant only in recent period. The observed inverse relation suggests that the firms with high liquidity are unable to raise long-term debt. This is possibly due to agency cost associated with free cash flow. Moreover, the liquid assets do not support for long-term borrowings as the lenders are exposed to the risk that the management may shift to riskier projects or the firm's conditions deteriorate over time.

\footnotetext{
${ }^{13}$ Newberry and Novack (1999) and Dennis et al. (2000) report a positive relationship while Barclay and Smith (1995) and Guedes and Opler (1996) report a negative relation.

${ }_{14}$ When the sample is divided into two sub-periods, the significance of this variable disappears.
} 
Earnings volatility: The estimates (table 7) show that the effect of earnings volatility on debt maturity is country dependent with no significant influence on the debt maturity decisions of German firms, positive on French firms and negative on British firms. The positive relation between the debt maturity and earnings volatility of French firms implies that French firms with volatile earnings issue long-term debt to avoid possible liquidation. On the other hand, British firms with high volatile earnings raise less long-term debt, possibly to avoid any long-term commitment.

Firm's quality: The signalling hypothesis predicts a negative relation between firm's quality and debt maturity. However, like Dennis et al. (2000), we find no support for this hypothesis in any of the sample countries, except during the first sub-sample period in France. There are several possible explanations for the observed insignificant relation. First, short-term debt may cause inefficient liquidation and, thus, high quality firms prefer a combination of short- and long-term debt (Diamond, 1993). Second, a non-monotonic relationship between debt maturity and firm quality may exist, that is only medium-rated firms issue long-term debt, and very low-rated and high-rated firms choose short-term debt (Diamond, 1991) ${ }^{16}$. Finally, in code-law countries where the relationship between major stakeholders and managers is closer, potential problems of asymmetric information are likely to be less severe than in common-law countries (Ball et al., 2000). The insignificant relation in Germany and France may partly be explained by this argument.

Overall, the results lend mixed support for the liquidity risk and signalling hypotheses. Firms in all countries seem to take the potential threat of bankruptcy seriously while setting their debt maturity structure. The relevance of these hypotheses to firms is found to be country dependent.

\subsection{Contracting Costs}

Market-to-book ratio: The estimates (table 7) reveal that the market-to-book ratio (a proxy for growth opportunities) has no significant effect on debt maturity of firms operating in any of the sample countries (except some evidence of support in Germany prior to 1992). This refutes the predictions of the contracting cost hypothesis. The insignificant association implies that suboptimal investment concerns are not important. This may be due to Chan-Lau's (2001) argument that the advantages of a specific corporate governance system are not necessarily

\footnotetext{
${ }^{15}$ Estimates based on alternative measures of leverage are qualitatively similar.

16 The prediction of an inverted-U shape relation between firm's quality and debt maturity has strong empirical support in Stohs and Mauer (1996). To test for this, we used a squared-quality variable (if quality $<0$ it is multiplied by -1 to retain the original sign). It is expected that maturity should be positively correlated with quality and negatively correlated with squared-quality, such that maturity increases as firm's quality deteriorates at a decreasing rate. The coefficients were statistically insignificant in all cases.
} 
related to informational asymmetries; apart from mitigating the shareholders-managers conflicts, bank-oriented systems may also curtail the under-investment problem.

Firm Size: Table 7 shows that firm size has a significant and positive impact only on British firms' debt maturity decision ${ }^{17}$. This holds for sub-samples as well. The insignificant effect is in line with the conventional wisdom that indirect bankruptcy costs, implicit in firm size, are less in Germanic and Latinic economies than in Anglo-Saxon economies, due to the corporate ownership structure and the long-run relationship between firms and their external financiers. This argument is further supported by the significant and positive effect of this variable in the UK. These findings confirm the arguments related to affordable transaction costs, easy access to capital markets, lower informational asymmetries, reputational considerations, and weak incentive problems, which are all relevant factors when larger firms issue long-term debt.

Asset maturity structure: Consistent with most empirical studies referred to earlier we find a significant and positive relationship between asset maturity and debt maturity of French and German firms for the full sample period (table 7). This supports the view that firms match the maturities of assets and liabilities (the immunisation hypothesis). However, asset maturity appears to have no significant impact on the debt maturity decisions of British firms. The combination of the insignificant coefficients of both market-to-book ratio and asset maturity supports the life cycle theory of firms. It also implies an absence of an under-investment problem in the UK.

Thus, the contracting cost hypothesis receives mixed support.

\subsection{Equity Market Conditions}

Share price performance: The association of debt maturity with share price performance varies across countries (table 7). In France, changes in stock prices do not have any significant effect on debt maturity decision of firms. However, this relationship is positive and significant for full sample in Germany and for full sample and second sub-sample in the UK. The positive relation confirms the predictions of the asymmetric information models (Lucas and McDonald, 1990) that firms issue informationally disadvantaged securities (e.g. long-term debt) after the rise in their share prices.

Equity risk premium: Table 7 further shows that the association of debt maturity with equity premium also depends on country and sample period. It is positive and significant in Germany

17 Size measured by total assets did not alter the quality of results. 
and the UK, but insignificant in France. This suggests that firms in France take debt maturity decisions without considering the equity market conditions. On the contrary, British and German firms issue long-term debt if the equity premium is high, reflecting managers' attempt to minimise the cost of capital by making a choice between the sources of funding. Unsurprisingly, this finding is stronger in the case of a market oriented economy, the UK.

In summary, the results show that most of the factors identified in the literature as determinants of corporate debt maturity structure are found significant in the case of British firms, but not for German and French firms. The overall explanatory power of the model (the coefficient of determination) is relatively higher for the UK. Thus, the results clearly support the view that corporate financial decisions are not only dependent on company specific factors, but they are also guided by the financial, legal and corporate governance traditions of the country in which the firms operate.

\section{Conclusion}

The paper identifies the determinants of corporate debt maturity structure in three major European countries (France, Germany and the UK) using a dynamic system-GMM. The three main strands of debt maturity theories that we test simultaneously are (a) the tax minimisation theory (b) the information asymmetry (liquidity and signalling) theory and (c) the contracting costs theory. We allow for dynamism in debt maturity structure and control for possible implications of market factors by incorporating a bridge between equity and debt markets. Several conclusions emerge. First, firms in all three countries appear to adjust their debt maturity structure towards their target level. The French firms are swifter than their British and German counterparts. The speed of adjustment has increased in recent years in France and the UK, possibly due to improved capital markets.

Second, the tax minimisation hypothesis - that predicts when the term-structure of interest rates is upward sloping, long-term debt is optimal - receives some support in all countries. The effective tax rate has a significant and positive influence on the length of debt maturity in Germany. The term-structure of interest rates influences the debt maturity choice of firms in all three countries, and the volatility in the rate of interest affects the debt maturity choice of UK firms. Further, the evidence from Germany supports the tax clientele argument that high marginal tax rates encourage firms to borrow for longer-term.

Third, the liquidity risk hypothesis (information asymmetry theory) also receives some support. Confirming the managerial objective of reducing bankruptcy risk, a significant and positive effect of leverage on debt maturity is found in all countries. Similarly, liquidity plays an important role 
on debt maturity decisions of the firms operating in all countries reflecting the need to avoid costly and lengthy bankruptcy process. Further, the firm level volatility has a significant impact on French and British firms reflecting the importance of risk. However, the debt maturity structure of firms remains independent of firm quality in all countries. Overall, the liquidity risk hypothesis of debt maturity receives mixed support.

Fourth, all factors representing the contracting (agency) cost hypothesis affect the debt maturity decisions of the UK firms. However, these factors have no significant effect in France and Germany. Finally, the evidence further supports that UK firms consider equity market conditions when deciding their debt maturity structure while the German and French don't. A prediction of the signalling hypothesis that firms issue long-term debt after an increase in their share price holds in Germany and the UK. Thus, the influence of equity market conditions on corporate debt maturity structure is country dependent.

In summary, corporate objectives such as minimising tax, bankruptcy risk and agency costs exert some influence on the debt maturity structure of firms in all three countries. Moreover, we identify some market related factors that have substantial impact on the debt maturity structure of firms, especially in a market based economy like the UK. However, the nature and the magnitude of the effects of these factors are country dependent reflecting the influences of the financial environment, regulations, and corporate governance traditions of the country in which the firm operates. 


\section{REFERENCES}

Anderson, T. W. and Hsiao, C., 'Formulation and estimation of dynamic models using panel data', Journal of Econometrics, Vol. 18, 1982, pp. 47-82.

Antoniou, A., Guney, Y. and Paudyal, K., 'Determinants of corporate capital structure: evidence from European countries', Working Paper, University of Durham, 2002.

Arellano, M. and Bond, S., 'Some tests of specification for panel data', Review of Economic Studies, Vol. 58, 1991, pp. 277-297.

Arellano, M. and Bover, O., 'Another look at the instrumental variable estimation of errorcomponents models', Journal of Econometrics, Vol. 68, 1995, pp. 29-51.

Baker, M. and Wurgler, J., 'The equity share in new issues and aggregate stock returns', Journal of Finance, Vol. 55, 2000, pp. 2219-2257.

Ball, R., Kothari, S. P., and Robin, A., 'The effect of international institutional factors on properties of accounting earnings', Journal of Accounting and Economics, Vol. 29, 2000, pp. 151.

Barclay, M. J. and Smith, C. W., 'The maturity structure of corporate debt', Journal of Finance, Vol. 50, 1995, pp. 609-631.

Barnea, A., Haugen, R. A. and Senbet, L. W., 'A rationale for debt maturity structure and call provisions in the agency theoretic framework', Journal of Finance, Vol. 35, 1980, pp. 1223-1234.

Blundell, R. W. and Bond, S. R., 'Initial conditions and moment restrictions in dynamic panel data models', Journal of Econometrics, Vol. 87, 1998, pp. 115-143.

Brick, I. E. and Ravid, S. A., 'On the relevance of debt maturity structure', Journal of Finance, Vol. 40, 1985, pp. 1423-1437.

Brick, I. E. and Ravid, S. A., 'Interest rate uncertainty and the optimal debt maturity structure', Journal of Financial and Quantitative Analysis, Vol. 26, 1991, pp. 63-81.

Chan-Lau, J. A., 'The impact of corporate governance structures on the agency cost of debt', IMF Working Paper, WP/01/204, 2001.

Datta, S. and Iskandar-Datta, M., 'Debt structure adjustments and long-run stock price performance', Journal of Financial Intermediation, Vol. 9, 2000, pp. 427-453.

Dennis, S., Nandy, D. and Sharpe, I. G., 'The determinants of contract terms in bank revolving credit agreements', Journal of Financial and Quantitative Analysis, Vol. 35, 2000, pp. 87-110.

Diamond, D. W., 'Debt maturity structure and liquidity risk', Quarterly Journal of Economics, Vol. 106, 1991, pp. 709-737.

Diamond, D. W., 'Seniority and maturity of debt contracts', Journal of Financial Economics, Vol. 33, 1993, pp. 341-368.

Fama, E. F., 'Contract costs and financing decisions', Journal of Business, Vol. 63, 1990, pp. S71-S91. 
Fan, J.P.H., Titman, S. and Twite, G., 'An international comparison of capital structure and debt maturity choices', EFA 2003 Conference, 2003.

Flannery, M. J., 'Asymmetric information and risky debt maturity choice', Journal of Finance, Vol. 41, 1986, pp. 19-37.

Graham, J. R. and Harvey, C. R., 'The theory and practice of corporate finance: evidence from the field', Journal of Financial Economics, Vol. 60, 2001, pp. 187-243.

Guedes, J. and Opler, T., 'The determinants of the maturity of corporate debt issues', Journal of Finance, Vol. 51, 1996, pp. 1809-1833.

Hart, O. and Moore, J., 'A theory of debt based on the inalienability of human capital', Quarterly Journal of Economics, Vol. 109, 1994, pp. 841-879.

Hart, O. and Moore, J., 'Debt and seniority: an analysis of the role of hard claims in constraining management', American Economic Review, Vol. 85, 1995, pp. 567-585.

Hsiao, C., 'Benefits and limitations of panel data', Econometric Reviews, Vol. 4, 1985, pp. 121174.

Jalilvand, A. and Harris, R. S., 'Corporate behaviour in adjusting to capital structure and dividend targets: an econometric study', Journal of Finance, Vol. 39, 1984, pp. 127-145.

Kane, A., Marcus, A. J. and McDonald, R. L., 'Debt policy and the rate of return premium to leverage', Journal of Financial and Quantitative Analysis, Vol. 20, 1985, pp. 479-499.

Kim, C. S., Mauer, D. C and Stohs, M. H, 'Corporate debt maturity policy and investor tax-timing options: theory and evidence', Financial Management, Vol. 24, 1995, pp. 33-45.

La Porta, R., Lopez-de-Silanes, F., Shleifer, A., Vishny, R.W. 'Law and Finance', Journal of Political Economy, Vol. 106, 1998, 1113-1155.

Leland, H. E. and Toft, K. B., 'Optimal capital structure, endogenous bankruptcy, and the term structure of credit spreads', Journal of Finance, Vol. 51, 1996, pp. 987-1019.

Lewis, C. M., 'A multiperiod theory of corporate financial policy under taxation', Journal of Financial and Quantitative Analysis, Vol. 25, 1990, pp. 25-44.

Lucas, D. and McDonald, R., 'Equity issues and stock price dynamics', Journal of Finance, Vol. 45, 1990, pp. 1020-1043.

Mitchell, K., 'The call, sinking fund and term-to-maturity features of corporate bonds: an empirical investigation', Journal of Financial and Quantitative Analysis, Vol. 26, 1991, pp. 201221.

Mitchell, K., 'The debt maturity choice: an empirical investigation', Journal of Financial Research, Vol. 16, 1993, pp. 309-320.

Morris, J. R., 'Factors affecting the maturity structure of corporate debt', Working Paper, College of Business and Administration, University of Colorado at Denver, 1992.

Myers, S. C., 'Determinants of corporate borrowing', Journal of Financial Economics, Vol. 5, 1977, pp. 147-175. 
Myers, S.C., 'The capital structure puzzle', Journal of Finance, Vol. 39, 1984, pp. 575-592.

Myers, S. C. and Rajan, R. G., 'The paradox of liquidity', Quarterly Journal of Economics, Vol. 113, 1998, pp. 733-771.

Newberry, K. J. and Novack, G. F., 'The effects of taxes on corporate debt maturity decisions: an analysis of public and private bond offerings', Journal of American Taxation Association, Vol. 21, 1999, pp. 1-16.

Sarkar, S., 'Illiquidity risk, project characteristics, and the optimal maturity of corporate debt', Journal of Financial Research, Vol. 22, 1999, pp. 353-370.

Scherr, F. C. and Hulburt, H. M., 'The debt maturity structure of small firms', Financial Management, Vol. 30, 2001, pp. 85-111.

Schiantarelli, F. and Sembenelli, A., 'The maturity structure of debt: determinants and effects on firms' performance: evidence from the UK and Italy', Policy Research Working Paper \#1699, World Bank, 1997.

Scholes, M. S. and Wolfson, M., Taxes and business strategy: a planning approach, PrenticeHall, Englewood Cliffs, NJ, 1992.

Stohs, M. H. and Mauer, D. C., 'The determinants of corporate debt maturity structure', Journal of Business, Vol. 69, 1996, pp. 279-312

Titman, S., 'Interest rate swaps and corporate financing choices', Journal of Finance, Vol. 47, 1992, pp. 1503-1516.

Titman, S. and Wessels, R., 'The determinants of capital structure choice', Journal of Finance, Vol. 43, 1988, pp. 1-19. 
Table 1

The relation between the variables and theories

(Hypotheses and predicted signs)

The major theories and the determinants of corporate debt maturity structure and their expected relation (sign) are summarised in this table. The variables are defined in the text. Some variables are related to more than one group of hypotheses of debt maturity structure.

\begin{tabular}{|c|c|c|c|c|c|c|c|c|c|}
\hline & Tax savings & Liquidation & Risk and & ignalling & & Agency/Con & racting Cost & & Equity Market \\
\hline & Tax & Bankruptcy & Liquidity & Signalling & $\begin{array}{c}\text { Under- } \\
\text { investment }\end{array}$ & $\begin{array}{c}\text { Asset } \\
\text { Substitution }\end{array}$ & $\begin{array}{c}\text { Over- } \\
\text { investment }\end{array}$ & Monitoring & \\
\hline Lagged Maturity & + & 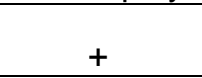 & & & & & & 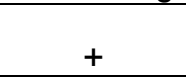 & \\
\hline Effective Tax rate & + & & & & & & & & \\
\hline Interest Rate Volatility & + & & + & & & & & & \\
\hline Term Structure & + & & & & & & & & \\
\hline Leverage & & - & + & & - & & & & \\
\hline Liquidity & & & - & & & + & & & \\
\hline Firm Quality & & & & - & & & & & \\
\hline Earnings Volatility & - & - & & & & & & & \\
\hline Market-to-book ratio & & - & + & & - & & + & - & \\
\hline Firm size & & + & & & + & + & & & \\
\hline Asset Maturity & & & + & & + & & & & \\
\hline Share Price Performance & & & & & & & & & + \\
\hline Market Equity Premium & & & & & & & & & - \\
\hline
\end{tabular}


Table 2

Summary statistics of firm specific variables

Maturity is the ratio of debt that matures in more than one year to total debt. Leverage is the ratio of book value of total debt to book value of total assets. Tax rate is the ratio of total tax charge to total taxable income. Market-to-book is the ratio of book value of total assets less book value of equity plus market value of equity to book value of total assets. Size is the natural logarithm of total sales. Liquidity is the ratio of current assets to total assets. Asset maturity is the ratio of net property, plant \&equipment to depreciation expense. Firm Quality is the ratio of net income plus depreciation to net debt. Earnings volatility is the first-difference of earnings minus average of the first-differences. Share price performance is the difference of log of annual share prices.

\section{Panel A: France}

Maturity

Mean

Leverage

0.59

Median

0.61

Std.dev

0.27

Variance Kurt

Kurtosis

0.23

0.22

0.14

0.32

Market-to-book ratio

1.57

14.84

0.35

0.46

1.23

14.85

1.31

Liquidity

0.60

0.62

1.93

0.19

Asset maturity

Firm Quality

Earnings volatility

5.87

4.91

5.78

0.24

0.76

0.37

17.85

5.85

0.41

$$
0.07
$$

$-0.60$

0.63

62.38

0.21

1.71

3.74

155.52

0.04

33.43

0.96

$-0.29$

$318.60 \quad 183.34$

$34.26 \quad 2058.76$

Skew.

Min.

Max. N-Obs.

$\begin{array}{ll}-0.28 & 0.00\end{array}$

$1.00 \quad 3160$

$\begin{array}{llll}0.65 & 0.00 & 1.00 & 3160\end{array}$

$3.20 \quad-3.97$

$6.78 \quad 3160$

$9.23 \quad 0.48$

$33.36 \quad 3160$

$\begin{array}{ll}-0.25 & 0.00\end{array}$

$20.23 \quad 3160$

$\begin{array}{ll}-0.43 \quad 0.01 \\ 7.09 & 0.03\end{array}$

$0.98 \quad 3160$

0.20

0.17

2.47

$-2.43-327.72$

$92.95 \quad 3160$

$282.80 \quad 3140$

\section{Panel B: Germany}

Maturity

Leverage

Tax rate

Market-to-book ratio

Size

Liquidity

Asset maturity

Firm Quality

Earnings volatility

Share price performance

\section{Panel C: UK}

Maturity

Leverage

Tax rate

Market-to-book ratio

Size

Liquidity

Asset maturity

Firm Quality

Earnings volatility

Share price performance
Mean

0.53

0.20

0.39

2.01

12.34

0.55

7.73

$-0.28$

3.30

0.01

Median

0.57

0.15

0.45

1.32

12.38

0.58

5.27

0.22

0.37

0.00

Mean

0.46

0.17

0.36

1.47

9.03

0.57

13.58

0.63

1.12

0.06

Median

0.47

0.15

0.36

1.11

8.86

0.61

9.34

0.48

0.25

0.07
Std.dev

0.31

0.19

1.03

3.83

2.31

0.23

11.01

34.14

19.94

0.34

Std.dev

0.34

0.14

0.55

1.96

1.89

0.21

17.80

28.92

8.04

0.47
Variance

0.10

0.04

1.06

14.65

5.31

0.05

121.13

1165.49

397.52

0.12
Variance

0.11

0.02

0.31

3.83

3.57

0.05

316.93

836.58

64.71

0.22
Kurtosis

$-1.10$

$$
0.42
$$

110.21

243.03

0.65

$-0.62$

76.92

138.43

535.95

4.13

Kurtosis

$-1.36$

2.80

470.55

727.15

0.65

$-0.34$

66.75

568.46

2767.91

3.35
$289.62 \quad 2889$

$2.37 \quad 2867$

0.04

0.00

$-2.35$

Skew.

$-0.29$

$0.98 \quad 0.00$

$-0.14 \quad-16.47$

$13.50 \quad 0.25$

$-0.25 \quad 1.23$

$-0.38 \quad 0.00$

$7.44 \quad 0.00$

$4.50-0.48$

$19.64 \quad 0.00$

$0.35 \quad-2.23$

Skew.

0.03

1.22

$\begin{array}{ll}-3.92 & -18.50\end{array}$

$21.07 \quad 0.12$

$0.19 \quad 0.02$

$\begin{array}{ll}-0.54 & 0.01\end{array}$

$6.75 \quad 0.00$

$1.81-983.00$

$44.65 \quad 0.00$

$-0.34 \quad-4.01$

Min.

0.00

.00

$1.00 \quad 32339$

$1.00 \quad 35266$

$18.43 \quad 35248$

$94.76 \quad 34848$

$16.22 \quad 35111$

$1.00 \quad 35244$

$282.63 \quad 35157$

$961.00 \quad 35198$

$660.76 \quad 32835$

$3.30 \quad 32854$ 
Table 3

Correlation matrix

See table 2 for firm-specific variable definitions. Interest rate volatility is the standard deviation of the monthly government bond yield over the previous year, matched with the month of firm's fiscal year-end. Equity premium is the difference between return on equity and return on treasury-bills, matched to the month of the firm's fiscal year-end, with a six-month lag. Term-structure is the difference between the month-end yields on long-term government bonds and three-months treasury-bills, matched to the month of the firm's fiscal year-end, with a six-month lag. ${ }^{* \star}$ and ${ }^{*}$ show that the correlation is significant at $1 \%$ and $5 \%$ level, respectively.

\section{Panel A: France}

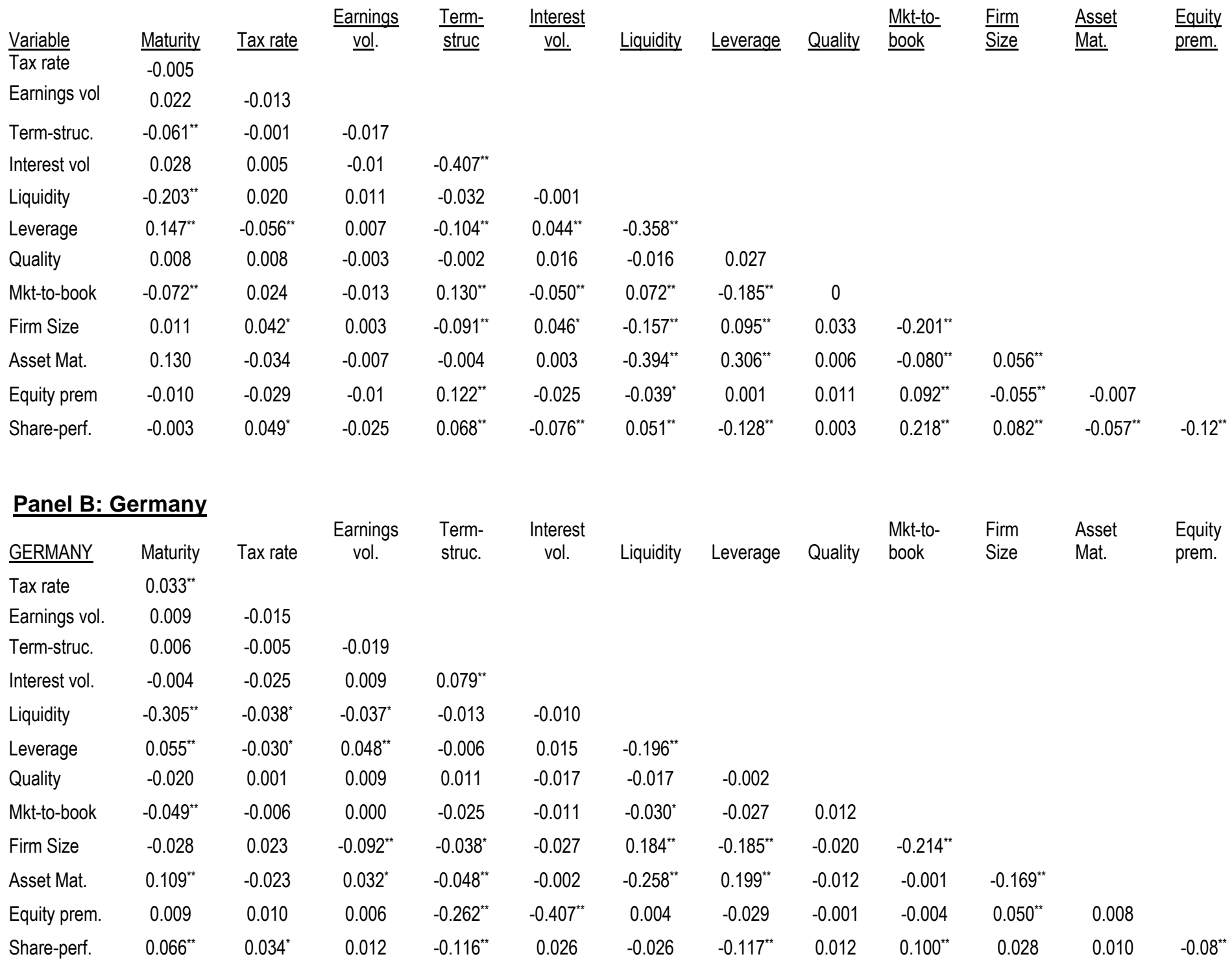

Table 3 continued 


\section{Panel C: UK}

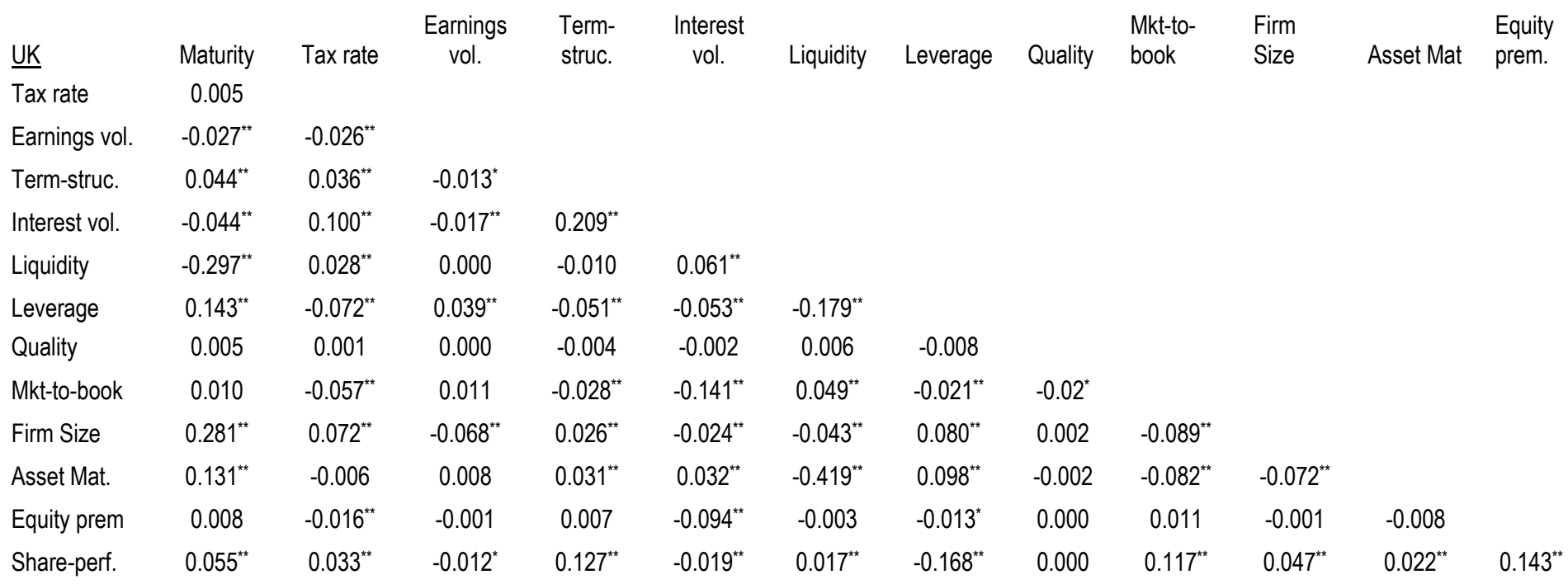


Table 4

Dynamic corporate debt maturity structure:

GMM-DIF (first-differenced GMM) vs. WITHIN (fixed-effects) estimations

See table 2 and 3 for variable definitions. The 'Theory' column represents the debt maturity theories as follows: $D=m a t u r i t y$ dynamics, $\mathrm{T}$ =taxes, $\mathrm{LS}=$ liquidity and signalling, $\mathrm{C}=$ contracting costs, and $\mathrm{M}=$ equity market. The dependent variable 'Maturity' is the ratio of long-term debt (maturing in more than one year) to total debt. Standard Errors are in parentheses below the coefficients. Correlation 1 and 2 are first and second order autocorrelation of residuals, respectively; which are asymptotically distributed as $N(0,1)$ under the null of no serial correlation. Sargan Test is the test of over identifying restrictions, asymptotically distributed as $x^{2}(\mathrm{df})$ under the null of instruments' validity. Wald Test- 1 test the joint significance of estimated coefficients; asymptotically distributed as $X^{2}(\mathrm{df})$ under the null of no relationship. $\left({ }^{*}\right),\left({ }^{* *}\right)$ and $\left({ }^{* * *}\right)$ indicates that coefficients are significant or the relevant null is rejected at 10, 5 and 1 percent level, respectively.

\begin{tabular}{|c|c|c|c|c|c|c|c|c|}
\hline \multicolumn{9}{|c|}{ Dependent Variable: Maturity $y_{i, t}$} \\
\hline \multirow{2}{*}{$\begin{array}{l}\text { Explanatory } \\
\text { Variables }\end{array}$} & \multirow[t]{2}{*}{ Theory } & \multirow{2}{*}{$\begin{array}{l}\text { Predicted } \\
\text { Sign }\end{array}$} & \multicolumn{2}{|c|}{ FRANCE } & \multicolumn{2}{|c|}{ GERMANY } & \multicolumn{2}{|c|}{ UK } \\
\hline & & & WITHIN & GMM-DIF & WITHIN & GMM-DIF & WITHIN & GMM-DIF \\
\hline Maturity ${ }_{i, t-1}$ & $\mathrm{D}$ & + & $\begin{array}{c}0.3702^{* * *} \\
(0.0333)\end{array}$ & $\begin{array}{l}0.3494^{* \star *} \\
(0.0531)\end{array}$ & $\begin{array}{c}0.3642^{\star \star \star} \\
(0.0262)\end{array}$ & $\begin{array}{c}0.4179^{* \star *} \\
(0.0474)\end{array}$ & $\begin{array}{l}0.5270^{\star \star *} \\
(0.0088)\end{array}$ & $\begin{array}{c}0.5578^{* * *} \\
(0.0313)\end{array}$ \\
\hline Effective tax rate ${ }_{i, t}$ & $\mathrm{~T}$ & $-/+$ & $\begin{array}{c}0.0021 \\
(0.0055)\end{array}$ & $\begin{array}{c}0.0000 \\
(0.0079)\end{array}$ & $\begin{array}{c}0.0023 \\
(0.0034)\end{array}$ & $\begin{array}{c}0.0042 \\
(0.0047)\end{array}$ & $\begin{array}{c}0.0007 \\
(0.0025)\end{array}$ & $\begin{array}{c}0.0114 \\
(0.0199)\end{array}$ \\
\hline Earnings vol.i,t & $\mathrm{T}$ & - & $\begin{array}{c}0.0008 \\
(0.0018)\end{array}$ & $\begin{array}{c}0.0012 \\
(0.0018)\end{array}$ & $\begin{array}{l}-0.0001 \\
(0.0005)\end{array}$ & $\begin{array}{l}-0.0005 \\
(0.0009)\end{array}$ & $\begin{array}{c}0.0001 \\
(0.0002)\end{array}$ & $\begin{array}{l}-0.0015 \\
(0.0015)\end{array}$ \\
\hline Term-structure & $\mathrm{T}$ & + & $\begin{array}{l}-0.0020 \\
(0.0333)\end{array}$ & $\begin{array}{l}-0.0163 \\
(0.0400)\end{array}$ & $\begin{array}{l}0.0573^{\star *} \\
(0.0270)\end{array}$ & $\begin{array}{c}0.0246 \\
(0.0352)\end{array}$ & $\begin{array}{c}0.0346^{\star * *} \\
(0.0069)\end{array}$ & $\begin{array}{c}0.0416^{\star * *} \\
(0.0097)\end{array}$ \\
\hline Interest vol. & $\mathrm{T}$ & + & $\begin{array}{l}-0.0036 \\
(0.0070)\end{array}$ & $\begin{array}{l}-0.0053 \\
(0.0072)\end{array}$ & $\begin{array}{c}0.0210 \\
(0.0212)\end{array}$ & $\begin{array}{c}0.0211 \\
(0.0289)\end{array}$ & $\begin{array}{c}-0.0102^{* *} \\
(0.0044)\end{array}$ & $\begin{array}{c}-0.0140^{* * *} \\
(0.0065)\end{array}$ \\
\hline Liquidityi,t & LS & $-1+$ & $\begin{array}{l}-0.1673^{*} \\
(0.0961)\end{array}$ & $\begin{array}{c}0.1017 \\
(0.1338)\end{array}$ & $\begin{array}{c}-0.3612^{* * *} \\
(0.0693)\end{array}$ & $\begin{array}{l}-0.2383 \\
(0.2010)\end{array}$ & $\begin{array}{c}-0.1890^{* * *} \\
(0.0277)\end{array}$ & $\begin{array}{c}-0.2749^{\star * *} \\
(0.0865)\end{array}$ \\
\hline Leverage $_{i, t}$ & LS & $-/+$ & $\begin{array}{c}0.0854 \\
(0.0717)\end{array}$ & $\begin{array}{l}-0.0234 \\
(0.1017)\end{array}$ & $\begin{array}{c}-0.1496^{* *} \\
(0.0602)\end{array}$ & $\begin{array}{c}-0.3144^{\star *} \\
(0.1394)\end{array}$ & $\begin{array}{c}-0.1094^{\star \star *} \\
(0.0278)\end{array}$ & $\begin{array}{l}-0.0966 \\
(0.0828)\end{array}$ \\
\hline Firm Qualityi.t & LS & - & $\begin{array}{l}-0.0001 \\
(0.0002)\end{array}$ & $\begin{array}{c}0.0001 \\
(0.0002)\end{array}$ & $\begin{array}{l}-0.0003^{*} \\
(0.0002)\end{array}$ & $\begin{array}{l}-0.0001 \\
(0.0003)\end{array}$ & $\begin{array}{l}0.0001^{* *} \\
(0.0001)\end{array}$ & $\begin{array}{c}0.0009 \\
(0.0006)\end{array}$ \\
\hline Mkt-to-booki,t & C & $-/+$ & $\begin{array}{l}-0.0026 \\
(0.0087)\end{array}$ & $\begin{array}{l}-0.0054 \\
(0.0151)\end{array}$ & $\begin{array}{l}-0.0033 \\
(0.0022)\end{array}$ & $\begin{array}{c}0.0025 \\
(0.0124)\end{array}$ & $\begin{array}{c}0.0011 \\
(0.0020)\end{array}$ & $\begin{array}{l}-0.0014 \\
(0.0064)\end{array}$ \\
\hline Firm size $i, t$ & C & + & $\begin{array}{c}0.0112 \\
(0.0197)\end{array}$ & $\begin{array}{c}0.0195 \\
(0.0299)\end{array}$ & $\begin{array}{c}0.0131 \\
(0.0125)\end{array}$ & $\begin{array}{c}0.0418 \\
(0.0383)\end{array}$ & $\begin{array}{c}0.0398^{\star * *} \\
(0.0065)\end{array}$ & $\begin{array}{c}0.0183 \\
(0.0206)\end{array}$ \\
\hline Asset maturity $\mathrm{y}_{\mathrm{t}, \mathrm{t}}$ & C & + & $\begin{array}{l}0.0023^{*} \\
(0.0014)\end{array}$ & $\begin{array}{l}0.0036^{\star} \\
(0.0020)\end{array}$ & $\begin{array}{c}0.0008 \\
(0.0005)\end{array}$ & $\begin{array}{c}0.0015 \\
(0.0015)\end{array}$ & $\begin{array}{c}0.0008^{\star \star *} \\
(0.0002)\end{array}$ & $\begin{array}{c}0.0000 \\
(0.0007)\end{array}$ \\
\hline Equity premium & $M$ & $-/+$ & $\begin{array}{c}0.0003 \\
(0.0006)\end{array}$ & $\begin{array}{c}0.0002 \\
(0.0007)\end{array}$ & $\begin{array}{l}-0.0002 \\
(0.0010)\end{array}$ & $\begin{array}{c}0.0008 \\
(0.0016)\end{array}$ & $\begin{array}{c}0.0003 \\
(0.0002)\end{array}$ & $\begin{array}{c}0.0019^{* * *} \\
(0.0006)\end{array}$ \\
\hline Share-price perf. & M & + & $\begin{array}{c}0.0036 \\
(0.0101)\end{array}$ & $\begin{array}{c}0.0132 \\
(0.0139)\end{array}$ & $\begin{array}{l}0.0241^{* *} \\
(0.0108)\end{array}$ & $\begin{array}{l}-0.0130 \\
(0.0276)\end{array}$ & $\begin{array}{c}0.0193^{\star \star *} \\
(0.0033)\end{array}$ & $\begin{array}{c}0.0312^{\star * *} \\
(0.0092)\end{array}$ \\
\hline Correlation1 & & & $-1.739^{* * *}$ & $-5.763^{* * *}$ & $-3.747^{\star * \star}$ & $-8.854^{* * *}$ & $-5.659^{* * *}$ & $-16.39^{* * *}$ \\
\hline Correlation2 & & & 0.0794 & 1.514 & $-2.873^{\star \star \star}$ & 0.1074 & 0.6368 & 1.897 \\
\hline Sargan Test (df) & & & - & $243(499)$ & - & $207(185)$ & - & $326(248)$ \\
\hline Wald Test-1 (df) & & & $206(21)^{\star \star \star}$ & $74.92(21)^{\star \star *}$ & $311(21)^{\star * *}$ & $105(21)^{\star \star \star}$ & $5148(21)^{\star * *}$ & $577(21)^{\star \star \star *}$ \\
\hline $\mathrm{R}^{2}$ & & & 0.1742 & - & 0.1573 & - & 0.3196 & - \\
\hline Firms & & & 297 & 297 & 469 & 469 & 2093 & 2093 \\
\hline Observations & & & 2430 & 2133 & 3936 & 3467 & 26779 & 24703 \\
\hline Estimation Period & & & $1985-2000$ & $1986-2000$ & $1989-2000$ & $1990-2000$ & $1971-2000$ & $1972-2000$ \\
\hline
\end{tabular}


Table 5

Corporate debt maturity structure (all countries pooled)

(Short-run and long-run equilibrium using system-GMM estimations)

See tables 2 and 3 for variable definitions. The 'Theory' column represents the debt maturity theories as follows: $\mathrm{D}=$ maturity dynamics, $\mathrm{T}=$ taxes, $\mathrm{LS}=$ liquidity and signalling, $\mathrm{C}=$ contracting costs, and $\mathrm{M}=$ equity market. The dependent variable 'Maturity' is the ratio of long-term debt (maturing in more than one year) to total debt. Leverage is book leverage and the size is measured by sales. Standard Errors are in parentheses below the coefficients. Correlation 1 and 2 are first and second order autocorrelation of residuals, respectively; which are asymptotically distributed as $N(0,1)$ under the null of no serial correlation. Sargan Test is the test of over identifying restrictions, asymptotically distributed as $\mathrm{X}^{2}(\mathrm{df})$ under the null of instruments' validity. Wald Test- 1 test the joint significance of estimated coefficients; asymptotically distributed as $X^{2}(\mathrm{df})$ under the null of no relationship. $\left({ }^{\star}\right),\left({ }^{\star *}\right)$ and $\left({ }^{* * *}\right)$ indicates that coefficients are significant or the relevant null is rejected at 10, 5 and 1 percent level, respectively. Fifteen industry dummies (see appendix B) are included in all models. Wald test-2 tests the joint significance of industry dummies. The 'specific' estimates are obtained following the general-to-specific approach, i.e. by excluding the insignificant lagged explanatory variables from the estimation of a general dynamic model.

\begin{tabular}{|c|c|c|c|c|c|c|}
\hline \multirow{3}{*}{$\begin{array}{l}\text { Explanatory } \\
\text { Variables }\end{array}$} & \multicolumn{3}{|c|}{ Dependent Variable: } & \multicolumn{3}{|c|}{ Maturityi,t } \\
\hline & \multirow[t]{2}{*}{ Theory } & \multirow{2}{*}{$\begin{array}{l}\text { Predicted } \\
\text { Sign }\end{array}$} & \multicolumn{2}{|c|}{ General } & \multicolumn{2}{|c|}{ Specific } \\
\hline & & & Short-run & Long-run & Short-run & Long-run \\
\hline \multirow[t]{2}{*}{ Maturityi,t-1 } & $\mathrm{D}$ & + & $0.6718^{* * *}$ & - & $0.6737^{* \star *}$ & - \\
\hline & & & $(0.0257)$ & - & $(0.0256)$ & - \\
\hline \multirow[t]{2}{*}{ Effective tax rate $_{\mathrm{i}, \mathrm{t}}$} & $\mathrm{T}$ & $-/+$ & 0.0066 & 0.0183 & 0.0024 & 0.0075 \\
\hline & & & $(0.0170)$ & $(0.0650)$ & $(0.0184)$ & $(0.0564)$ \\
\hline \multirow[t]{2}{*}{ Earnings voli,t } & $\mathrm{T}$ & - & -0.0004 & -0.0017 & 0.0000 & -0.0001 \\
\hline & & & $(0.0007)$ & $(0.0024)$ & $(0.0007)$ & $(0.0023)$ \\
\hline \multirow[t]{2}{*}{ Term-structure } & $\mathrm{T}$ & + & $0.0267^{\star * *}$ & $0.0813^{\star \star \star}$ & $0.0285^{\star \star *}$ & $0.0875^{\star * *}$ \\
\hline & & & $(0.0078)$ & $(0.0243)$ & $(0.0077)$ & $(0.0242)$ \\
\hline \multirow[t]{2}{*}{ Interest vol. } & $\mathrm{T}$ & + & $-0.0097^{\star *}$ & $-0.0295^{\star \star}$ & $-0.0064^{*}$ & $-0.0195^{\star}$ \\
\hline & & & $(0.0041)$ & $(0.0127)$ & $(0.0040)$ & $(0.0122)$ \\
\hline \multirow[t]{2}{*}{ Liquidityi,t } & LS & $-/+$ & $-0.3207^{\star \star *}$ & $-0.5185^{\star \star *}$ & $-0.2763^{\star * *}$ & $-0.5024^{* * *}$ \\
\hline & & & $(0.1000)$ & $(0.0745)$ & $(0.1064)$ & $(0.0837)$ \\
\hline \multirow[t]{2}{*}{ Leverage $_{i, t}$} & LS & $-/+$ & $-0.2063^{* *}$ & $0.2724^{\star *}$ & $-0.1820^{\star *}$ & $0.2792^{\star *}$ \\
\hline & & & $(0.0977)$ & $(0.1259)$ & $(0.0941)$ & $(0.1223)$ \\
\hline \multirow[t]{2}{*}{ Firm Qualityi.t } & LS & - & 0.0003 & 0.0010 & 0.0005 & 0.0015 \\
\hline & & & $(0.0005)$ & $(0.0018)$ & $(0.0005)$ & $(0.0014)$ \\
\hline \multirow[t]{2}{*}{ Mkt-to-booki,t } & C & $-/+$ & 0.0051 & 0.0054 & 0.0014 & 0.0041 \\
\hline & & & $(0.0051)$ & $(0.0110)$ & $(0.0016)$ & $(0.0049)$ \\
\hline \multirow[t]{2}{*}{ Firm Size $e_{i, t}$} & C & + & -0.0144 & $0.0311^{\star \star \star}$ & $0.0197^{* \star *}$ & $0.0603^{* * *}$ \\
\hline & & & $(0.0242)$ & $(0.0040)$ & $(0.0044)$ & $(0.0130)$ \\
\hline \multirow[t]{2}{*}{ Asset maturity $\mathrm{y}_{\mathrm{i}, \mathrm{t}}$} & C & + & -0.0001 & 0.0004 & -0.0002 & -0.0006 \\
\hline & & & $(0.0008)$ & $(0.0013)$ & $(0.0006)$ & $(0.0019)$ \\
\hline \multirow[t]{2}{*}{ Equity premium } & M & $-/+$ & $0.0007^{* * *}$ & $0.0023^{* * *}$ & $0.0008^{* * *}$ & $0.0025^{\star * *}$ \\
\hline & & & $(0.0003)$ & $(0.0009)$ & $(0.0003)$ & $(0.0009)$ \\
\hline \multirow[t]{2}{*}{ Share-price perf. } & M & + & $0.0122^{\star * \star}$ & $0.0372^{\star \star *}$ & $0.0090^{\star *}$ & $0.0275^{\star *}$ \\
\hline & & & $(0.0044)$ & $(0.0132)$ & $(0.0037)$ & $(0.0110)$ \\
\hline \multirow[t]{2}{*}{ Dummy Germany } & & & -0.0112 & -0.0340 & 0.0081 & 0.0248 \\
\hline & & & $(0.0086)$ & $(0.0264)$ & $(0.0121)$ & $(0.0371)$ \\
\hline \multirow[t]{2}{*}{ Dummy UK } & & & $0.0275^{\star * *}$ & $0.0836^{* * *}$ & $0.0821^{* * *}$ & $0.2514^{* * *}$ \\
\hline & & & $(0.0102)$ & $(0.0306)$ & $(0.0251)$ & $(0.0772)$ \\
\hline \multirow[t]{2}{*}{ Constant } & & & $0.1121^{* * *}$ & $0.3418^{* * *}$ & -0.0405 & -0.1240 \\
\hline & & & $(0.0315)$ & $(0.0961)$ & $(0.0710)$ & $(0.2180)$ \\
\hline
\end{tabular}


Table 5 (continued)

\begin{tabular}{l|r|r|}
\hline & General & Specific \\
Correlation1 & $-20.28^{* * *}$ & $-20.56^{\star * *}$ \\
Correlation2 & 3.312 & 3.341 \\
Sargan Test (df) & $528(512)$ & $629(512)$ \\
Wald Test-1 (df) & $5286(23)^{\star * *}$ & $3717(17)^{\star * *}$ \\
Wald Test-2 (df) & $26.6(15)^{\star *}$ & $18.95(15)$ \\
$\mathrm{R}^{2}$ & 0.5865 & 0.5828 \\
Firms & 2859 & 3019 \\
Observations & 33145 & 35246 \\
Estimation Period & $1972-2000$ & $1971-2000$ \\
\hline
\end{tabular}


Table 6

Dynamic corporate debt maturity structure: System-GMM estimations

See tables 2 and 3 for variable definitions. The 'Theory' column represents the debt maturity theories as follows: $D=m a t u r i t y$ dynamics, $T=$ taxes, $L S=$ liquidity and signalling, $C=$ contracting costs, and $M=$ equity market. The dependent variable 'Maturity' is the ratio of long-term debt (maturing in more than one year) to total debt. Leverage is book leverage and the size is measured by sales. Standard Errors are in parentheses below the coefficients. Correlation 1 and 2 are first and second order autocorrelation of residuals, respectively; which are asymptotically distributed as $N(0,1)$ under the null of no serial correlation. Sargan Test is the test of over identifying restrictions, asymptotically distributed as $\mathrm{X}^{2}(\mathrm{df})$ under the null of instruments' validity. Wald Test- 1 test the joint significance of estimated coefficients; asymptotically distributed as $x^{2}$ (df) under the null of no relationship. $\left({ }^{*}\right),\left({ }^{* *}\right)$ and $\left({ }^{* * *}\right)$ indicates that coefficients are significant or the relevant null is rejected at 10,5 and 1 percent level, respectively. Fifteen industry dummies (see appendix B) are included in all models. Wald test- 2 tests the joint significance of industry dummies. The 'specific' estimates are obtained following the general-to-specific approach, i.e. by excluding the insignificant lagged explanatory variables from the estimation of a general dynamic model.

\begin{tabular}{|c|c|c|c|c|c|c|c|c|}
\hline \multicolumn{9}{|c|}{ Dependent Variable: Maturityi,t } \\
\hline \multirow{2}{*}{$\begin{array}{l}\text { Explanatory } \\
\text { Variables }\end{array}$} & \multirow[t]{2}{*}{ Theory } & \multirow{2}{*}{$\begin{array}{l}\text { Predicted } \\
\text { Sign }\end{array}$} & \multicolumn{2}{|c|}{ FRANCE } & \multicolumn{2}{|c|}{ GERMANY } & \multicolumn{2}{|c|}{ UK } \\
\hline & & & General & Specific & General & Specific & General & Specific \\
\hline \multirow[t]{2}{*}{ Maturity $\mathrm{i}, \mathrm{t}-1$} & $\mathrm{D}$ & + & $0.4484^{* \star *}$ & $0.4702^{\star \star \star}$ & $0.4873^{* * *}$ & $0.4621^{\star * \star}$ & $0.6623^{\star * *}$ & $0.6691^{* * *}$ \\
\hline & & & $(0.0485)$ & $(0.0437)$ & $(0.0362)$ & $(0.0365)$ & $(0.0271)$ & $(0.0266)$ \\
\hline \multirow[t]{2}{*}{ Effective Tax rate $e_{i, t}$} & $\mathrm{~T}$ & $-/+$ & -0.0101 & -0.0191 & 0.0075 & $0.0193^{*}$ & -0.0157 & -0.0184 \\
\hline & & & $(0.0125)$ & $(0.0191)$ & $(0.0066)$ & $(0.0112)$ & $(0.0156)$ & $(0.0153)$ \\
\hline \multirow[t]{2}{*}{ Earnings voli,t } & $\mathrm{T}$ & - & 0.0043 & 0.0031 & -0.0002 & 0.0004 & -0.0016 & -0.0007 \\
\hline & & & $(0.0029)$ & $(0.0033)$ & $(0.0007)$ & $(0.0008)$ & $(0.0011)$ & $(0.0013)$ \\
\hline \multirow[t]{2}{*}{ Term-structure } & $\mathrm{T}$ & + & $-0.0616^{*}$ & $-0.0527^{*}$ & $0.0535^{\star \star}$ & $0.0672^{\star *}$ & $0.0280^{* * *}$ & $0.0293^{* * *}$ \\
\hline & & & $(0.0349)$ & $(0.0319)$ & $(0.0244)$ & $(0.0327)$ & $(0.0080)$ & $(0.0079)$ \\
\hline \multirow[t]{2}{*}{ Interest vol. } & $\mathrm{T}$ & + & -0.0026 & 0.0032 & 0.0023 & 0.0234 & $-0.0144^{\star \star *}$ & $-0.0148^{* * *}$ \\
\hline & & & $(0.0074)$ & $(0.0071)$ & $(0.0221)$ & $(0.0294)$ & $(0.0049)$ & $(0.0047)$ \\
\hline \multirow[t]{2}{*}{ Liquidity $_{\mathrm{i}, \mathrm{t}}$} & LS & $-/+$ & -0.1672 & -0.0194 & $-0.2726^{*}$ & $-0.1616^{*}$ & $-0.2122^{\star *}$ & $-0.1273^{* * *}$ \\
\hline & & & $(0.1763)$ & $(0.0808)$ & $(0.1566)$ & $(0.0978)$ & $(0.0986)$ & $(0.0463)$ \\
\hline \multirow[t]{2}{*}{ Leverage $_{i, t}$} & LS & $-/+$ & -0.1052 & -0.1390 & 0.0181 & $-0.1050^{*}$ & $-0.2320^{* *}$ & $-0.2280^{* *}$ \\
\hline & & & $(0.1014)$ & $(0.1087)$ & $(0.1467)$ & $(0.0626)$ & $(0.1010)$ & $(0.0995)$ \\
\hline \multirow[t]{2}{*}{ Firm Qualityi.t } & LS & - & 0.0000 & 0.0003 & -0.0001 & -0.0002 & 0.0004 & 0.0003 \\
\hline & & & $(0.0003)$ & $(0.0004)$ & $(0.0003)$ & $(0.0004)$ & $(0.0005)$ & $(0.0005)$ \\
\hline \multirow[t]{2}{*}{ Mkt-to-booki,t } & C & $-/+$ & -0.0003 & 0.0007 & -0.0005 & -0.0020 & 0.0042 & 0.0016 \\
\hline & & & $(0.0157)$ & $(0.0097)$ & $(0.0094)$ & $(0.0074)$ & $(0.0050)$ & $(0.0030)$ \\
\hline \multirow[t]{2}{*}{ Firm Size $i, t$} & C & + & $0.0385^{\star}$ & 0.0315 & -0.0068 & 0.0109 & -0.0238 & -0.0245 \\
\hline & & & $(0.0217)$ & $(0.0232)$ & $(0.0283)$ & $(0.0088)$ & $(0.0242)$ & (0.0239) \\
\hline \multirow[t]{2}{*}{ Asset maturity ${ }_{i, t}$} & C & + & 0.0019 & 0.0020 & 0.0012 & $0.0025^{\star *}$ & 0.0002 & 0.0001 \\
\hline & & & $(0.0021)$ & $(0.0018)$ & $(0.0012)$ & $(0.0013)$ & $(0.0008)$ & $(0.0006)$ \\
\hline \multirow[t]{2}{*}{ Equity premium } & M & $-/+$ & 0.0003 & 0.0002 & -0.0007 & $0.0028^{*}$ & $0.0008^{* * *}$ & $0.0008^{* * *}$ \\
\hline & & & $(0.0006)$ & $(0.0007)$ & $(0.0010)$ & $(0.0015)$ & $(0.0003)$ & $(0.0003)$ \\
\hline \multirow[t]{2}{*}{ Share-price perf. } & M & + & 0.0105 & 0.0085 & $0.0242^{\star *}$ & 0.0273 & $0.0123^{* \star *}$ & $0.0107^{* * *}$ \\
\hline & & & $(0.0109)$ & $(0.0100)$ & $(0.0125)$ & $(0.0223)$ & $(0.0047)$ & $(0.0044)$ \\
\hline \multirow[t]{2}{*}{ Constant } & & & $0.3253^{* * *}$ & $0.2525^{\star *}$ & $0.4335^{\star * *}$ & $0.2187^{*}$ & $0.1039^{* * *}$ & $0.1001^{* * *}$ \\
\hline & & & $(0.0970)$ & $(0.1043)$ & $(0.0708)$ & $(0.1344)$ & $(0.0281)$ & $(0.0371)$ \\
\hline Correlation1 & & & $-6.045^{\star \star \star}$ & $-6.740^{\star * *}$ & $-9.612^{\star \star \star}$ & $-9.792^{\star \star \star}$ & $-18.51^{* \star \star}$ & $-18.97^{\star * \star}$ \\
\hline Correlation2 & & & 1.0839 & 1.082 & 0.5337 & 0.4466 & 2.859 & 3.104 \\
\hline Sargan Test (df) & & & $252.1(647)$ & $273.3(656)$ & $297.9(296)$ & $316.5(301)$ & $601.5(612)$ & $593.5(612)$ \\
\hline Wald Test-1 (df) & & & $279.9(21)^{* * *}$ & $218.9(15)^{\star * *}$ & $488.2(21)^{* * *}$ & $258.4(13)^{\star * *}$ & $4848(21)^{\star * *}$ & $3282(15)^{\star * *}$ \\
\hline Wald Test-2 (df) & & & $47.55(15)^{\star \star \star}$ & $50.08(15)^{\star * *}$ & $62.75(14)^{\star \star \star}$ & $30.39(14)^{\star \star \star}$ & $28.52(15)^{\star \star}$ & $33.6(15)^{\star \star \star}$ \\
\hline $\mathrm{R}^{2}$ & & & 0.4948 & 0.4914 & 0.4940 & 0.4560 & 0.5894 & 0.5880 \\
\hline Firms & & & 297 & 328 & 469 & 482 & 2093 & 2211 \\
\hline Observations & & & 2430 & 2672 & 3936 & 4195 & 26779 & 28410 \\
\hline Estimation Period & & & $1986-2000$ & $1985-2000$ & $1990-2000$ & $1989-2000$ & $1972-2000$ & $1971-2000$ \\
\hline
\end{tabular}


Table 7

Static long-run relationship between debt maturity and firm- and market-specific factors

The parameters are estimated using equation (5) based on the models in table 5. See tables 2 and 3 for variable definitions. The 'Theory' column represents the debt maturity theories as follows: $D=$ maturity dynamics, $T=$ taxes, LS= liquidity and signalling, $\mathrm{C}=$ contracting costs, and $\mathrm{M}=$ equity market. The dependent variable 'Maturity' is the ratio of long-term debt (maturing in more than one year) to total debt. Leverage is book leverage and the size is measured by sales. Standard Errors are in parentheses below the coefficients. Correlation 1 and 2 are first and second order autocorrelation of residuals, respectively; which are asymptotically distributed as $N(0,1)$ under the null of no serial correlation. Sargan Test is the test of over identifying restrictions, asymptotically distributed as $\mathrm{X}^{2}(\mathrm{df})$ under the null of instruments' validity. Wald Test-1 test the joint significance of estimated coefficients; asymptotically distributed as $x^{2}(\mathrm{df})$ under the null of no relationship. $\left({ }^{*}\right)$, $\left({ }^{* *}\right)$ and $\left({ }^{* *}\right)$ indicates that coefficients are significant or the relevant null is rejected at 10,5 and 1 percent level, respectively. Fifteen industry dummies (see appendix B) are included in all models. Wald test-2 tests the joint significance of industry dummies. The 'specific' estimates are obtained following the general-to-specific approach, i.e. by excluding the insignificant lagged explanatory variables from the estimation of a general dynamic model.

\begin{tabular}{|c|c|c|c|c|c|c|c|c|}
\hline \multicolumn{9}{|c|}{ Dependent Variable: MATURITY $Y_{i, t}$} \\
\hline \multirow{2}{*}{$\begin{array}{l}\text { Explanatory } \\
\text { Variables }\end{array}$} & \multirow[t]{2}{*}{ Theory } & \multirow{2}{*}{$\begin{array}{l}\text { Predicted } \\
\text { Sign }\end{array}$} & \multicolumn{2}{|c|}{ FRANCE } & \multicolumn{2}{|c|}{ GERMANY } & \multicolumn{2}{|c|}{ UK } \\
\hline & & & General & Specific & General & Specific & General & Specific \\
\hline \multirow[t]{2}{*}{ Effective tax rate $e_{i, t}$} & $\mathrm{~T}$ & $-/+$ & -0.0239 & -0.0360 & 0.0159 & $0.0424^{* *}$ & -0.0648 & -0.0557 \\
\hline & & & $(0.0318)$ & $(0.0354)$ & $(0.0167)$ & $(0.0202)$ & $(0.0553)$ & $(0.0464)$ \\
\hline \multirow[t]{2}{*}{ Earnings voli,t } & $\mathrm{T}$ & - & $0.0079^{*}$ & 0.0058 & -0.0008 & 0.0008 & $-0.0065^{\star}$ & -0.0022 \\
\hline & & & $(0.0048)$ & $(0.0063)$ & $(0.0014)$ & $(0.0014)$ & $(0.0040)$ & $(0.0039)$ \\
\hline \multirow[t]{2}{*}{ Term-structure } & $\mathrm{T}$ & + & $-0.1116^{*}$ & $-0.0994^{*}$ & $0.1043^{\star *}$ & $0.1250^{* *}$ & $0.0828^{\star * *}$ & $0.0886^{\star * *}$ \\
\hline & & & $(0.0631)$ & $(0.0610)$ & $(0.0477)$ & $(0.0610)$ & $(0.0243)$ & $(0.0244)$ \\
\hline \multirow[t]{2}{*}{ Interest vol. } & $\mathrm{T}$ & + & -0.0047 & 0.0061 & 0.0045 & 0.0436 & $-0.0427^{\star \star \star}$ & $-0.0447^{\star \star \star *}$ \\
\hline & & & $(0.0133)$ & $(0.0134)$ & $(0.0430)$ & $(0.0546)$ & $(0.0148)$ & $(0.0146)$ \\
\hline \multirow[t]{2}{*}{ Liquidityi,t } & LS & $-/+$ & $-0.2045^{\star \star}$ & -0.0367 & $-0.5059^{* * *}$ & $-0.3024^{*}$ & $-0.4518^{* * *}$ & $-0.3847^{* * *}$ \\
\hline & & & $(0.1022)$ & $(0.1529)$ & $(0.0877)$ & $(0.1791)$ & $(0.0767)$ & $(0.1357)$ \\
\hline \multirow[t]{2}{*}{ Leverage $_{i, t}$} & LS & $-/+$ & $0.2152^{*}$ & $0.1951^{*}$ & 0.0047 & $-0.1952^{*}$ & $0.2571^{*}$ & $0.2448^{*}$ \\
\hline & & & $(0.1241)$ & $(0.1045)$ & $(0.1040)$ & $(0.1159)$ & $(0.1447)$ & $(0.1466)$ \\
\hline \multirow[t]{2}{*}{ Firm Qualityi.t } & LS & - & -0.0001 & 0.0006 & -0.0007 & -0.0003 & 0.0013 & 0.0010 \\
\hline & & & $(0.0007)$ & $(0.0008)$ & $(0.0007)$ & $(0.0008)$ & $(0.0018)$ & $(0.0015)$ \\
\hline \multirow[t]{2}{*}{ Mkt-to-booki,t } & C & $-/+$ & 0.0059 & 0.0013 & -0.0103 & -0.0037 & 0.0096 & 0.0047 \\
\hline & & & $(0.0184)$ & $(0.0183)$ & $(0.0090)$ & $(0.0138)$ & $(0.0110)$ & $(0.0090)$ \\
\hline \multirow[t]{2}{*}{ Firm size $e_{i, t}$} & C & + & -0.0026 & -0.0017 & -0.0035 & 0.0203 & $0.0433^{* \star *}$ & $0.0420^{* * *}$ \\
\hline & & & $(0.0080)$ & $(0.0074)$ & $(0.0064)$ & $(0.0163)$ & $(0.0049)$ & $(0.0051)$ \\
\hline \multirow[t]{2}{*}{ Asset maturity $\mathrm{y}_{\mathrm{i}, \mathrm{t}}$} & C & + & $0.0035^{\star *}$ & 0.0037 & 0.0014 & $0.0047^{*}$ & 0.0012 & 0.0002 \\
\hline & & & $(0.0016)$ & $(0.0034)$ & $(0.0018)$ & $(0.0024)$ & $(0.0012)$ & $(0.0018)$ \\
\hline \multirow[t]{2}{*}{ Equity premium } & $M$ & $-/+$ & 0.0006 & 0.0004 & -0.0013 & $0.0052^{*}$ & $0.0023^{\star \star \star}$ & $0.0026^{* * *}$ \\
\hline & & & $(0.0012)$ & $(0.0012)$ & $(0.0020)$ & $(0.0029)$ & $(0.0009)$ & $(0.0009)$ \\
\hline \multirow[t]{2}{*}{ Share-price perf. } & M & + & 0.0191 & 0.0160 & $0.0472^{* *}$ & 0.0507 & $0.0364^{* * *}$ & $0.0323^{* * *}$ \\
\hline & & & $(0.0197)$ & $(0.0188)$ & $(0.0242)$ & $(0.0408)$ & $(0.0137)$ & $(0.0131)$ \\
\hline \multirow[t]{2}{*}{ Constant } & & & $0.5898^{* * *}$ & $0.4767^{* *}$ & $0.8455^{\star \star \star}$ & $0.4066^{*}$ & $0.3076^{\star \star \star}$ & $0.3025^{\star \star *}$ \\
\hline & & & $(0.1695)$ & $(0.1988)$ & $(0.1243)$ & $(0.2470)$ & $(0.0833)$ & $(0.1114)$ \\
\hline
\end{tabular}


Appendix: A

The structure of panel data

The panel data are constructed as follows. All dead and alive firms whose data are available are included in the sample. The total number of non-financial firms stands at 1,235 for France, 1,590 for Germany, and 3,153 for the UK. The firms with any missing variable are excluded from the sample. The panel data set is unbalanced as there are more observations for some firms than for others. Sections in this appendix are as follows: a) Number of firms having ' $n$ ' continuous observations during the period; b) number of observations in each year; c) number of firms in each industry class; and d) number of observations in each industry class.

\begin{tabular}{|c|c|c|c|c|c|c|c|c|c|c|c|}
\hline \multicolumn{4}{|c|}{ a) Number of firms } & \multicolumn{4}{|c|}{ b) Number of observations } & \multicolumn{4}{|c|}{ c) Number of firms } \\
\hline$n$ (years) & France & Germany & UK & Years & France & Germany & UK & Industry & France & Germany & UK \\
\hline 3 & 60 & 22 & 207 & 1969 & - & - & 466 & 1 & 23 & 49 & 165 \\
\hline 4 & 54 & 26 & 218 & 1970 & - & - & 479 & 2 & 10 & 44 & 31 \\
\hline 5 & 33 & 35 & 196 & 1971 & - & - & 489 & 3 & 19 & 56 & 199 \\
\hline 6 & 13 & 26 & 128 & 1972 & - & - & 866 & 4 & 31 & 37 & 162 \\
\hline 7 & 22 & 9 & 98 & 1973 & - & - & 903 & 5 & 48 & 59 & 261 \\
\hline 8 & 17 & 9 & 67 & 1974 & - & - & 930 & 6 & 16 & 35 & 28 \\
\hline 9 & 14 & 8 & 56 & 1975 & - & - & 936 & 7 & 41 & 89 & 315 \\
\hline 10 & 12 & 8 & 52 & 1976 & - & - & 940 & 8 & 22 & 16 & 87 \\
\hline 11 & 1 & 13 & 87 & 1977 & - & - & 951 & 9 & 25 & 21 & 191 \\
\hline 12 & 47 & 24 & 91 & 1978 & - & - & 962 & 10 & 1 & 0 & 55 \\
\hline 13 & 16 & 38 & 82 & 1979 & - & - & 979 & 11 & 19 & 22 & 147 \\
\hline 14 & 5 & 364 & 89 & 1980 & - & - & 1000 & 12 & 31 & 23 & 254 \\
\hline 15 & 3 & - & 85 & 1981 & - & - & 1029 & 13 & 46 & 34 & 319 \\
\hline 16 & 3 & - & 65 & 1982 & - & - & 1067 & 14 & 17 & 64 & 142 \\
\hline 17 & 5 & - & 73 & 1983 & 59 & - & 1122 & 15 & 9 & 33 & 67 \\
\hline 18 & 53 & - & 68 & 1984 & 64 & - & 1200 & & & & \\
\hline 19 & - & - & 64 & 1985 & 67 & - & 1260 & & No. of ol & oservations & \\
\hline 20 & - & - & 50 & 1986 & 70 & - & 1303 & Industry & France & Germany & UK \\
\hline 21 & - & - & 34 & 1987 & 75 & 401 & 1314 & & & & \\
\hline 22 & - & - & 21 & 1988 & 92 & 418 & 1325 & 1 & 253 & 575 & 2580 \\
\hline 23 & - & - & 26 & 1989 & 142 & 437 & 1312 & 2 & 94 & 565 & 611 \\
\hline 24 & - & - & 20 & 1990 & 142 & 446 & 1288 & 3 & 235 & 689 & 3600 \\
\hline 25 & - & - & 26 & 1991 & 151 & 454 & 1247 & 4 & 268 & 462 & 2323 \\
\hline 26 & - & - & 23 & 1992 & 163 & 456 & 1216 & 5 & 375 & 593 & 3248 \\
\hline 27 & - & - & 44 & 1993 & 175 & 465 & 1222 & 6 & 153 & 437 & 476 \\
\hline 28 & - & - & 44 & 1994 & 197 & 473 & 1269 & 7 & 397 & 1120 & 5395 \\
\hline 29 & - & - & 165 & 1995 & 207 & 500 & 1318 & 8 & 186 & 199 & 1367 \\
\hline 30 & - & - & 27 & 1996 & 242 & 535 & 1402 & 9 & 217 & 238 & 2311 \\
\hline 31 & - & - & 39 & 1997 & 291 & 557 & 1483 & 10 & 4 & 0 & 585 \\
\hline \multirow[t]{5}{*}{32} & - & - & 178 & 1998 & 345 & 572 & 1471 & 11 & 143 & 269 & 2161 \\
\hline & & & & 1999 & 344 & 563 & 1340 & 12 & 296 & 275 & 3954 \\
\hline & & & & 2000 & 334 & 532 & 1177 & 13 & 348 & 225 & 3417 \\
\hline & & & & & & & & 14 & 141 & 760 & 2694 \\
\hline & & & & & & & & 15 & 50 & 402 & 544 \\
\hline Total & 358 & 582 & 2423 & Total & 3160 & 6809 & 35266 & & & & \\
\hline
\end{tabular}

